FIU Law Review

Spring 2015

\title{
Nation-State Culpability and Liability for Catastrophic Air Disasters: Reforming Public International Law to Allow for Liability of Nation-States and the Application of Punitive Damages
}

James A. Beckman

University of Central Florida

Follow this and additional works at: https://ecollections.law.fiu.edu/lawreview

Part of the Other Law Commons

Online ISSN: 2643-7759

Recommended Citation

James A. Beckman, Nation-State Culpability and Liability for Catastrophic Air Disasters: Reforming Public International Law to Allow for Liability of Nation-States and the Application of Punitive Damages, $10 \mathrm{FIU}$ L. Rev. 585 (2015).

DOI: https://dx.doi.org/10.25148/lawrev.10.2.15

This Article is brought to you for free and open access by eCollections. It has been accepted for inclusion in FIU Law Review by an authorized editor of eCollections. For more information, please contact lisdavis@fiu.edu. 


\title{
Nation-State Culpability and Liability for Catastrophic Air Disasters: Reforming Public International Law to Allow for Liability of Nation-States and the Application of Punitive Damages
}

\author{
James A. Beckman
}

\begin{abstract}
The genesis of this article came quickly after the tragic events of July 17, 2014, wherein Malaysian Airlines Flight 17 was intentionally shot down out of the skies over Donetsk Oblast, Ukraine, resulting in the murder of 283 passengers and 15 crew members. ${ }^{1}$ Like many around the globe, I was horrified not only as to a passenger plane being intentionally shot out of the skies in this day and age by Ukraine rebels (under the apparent training and support of Russia). I was additionally aghast that a government (in this instance, Russia) might not only be responsible for such a nefarious and insidious outcome, but could also be successful in evading legal and financial responsibility. ${ }^{2}$ Thus, this article examines whether a nation like Russia (assuming that it in fact supported, armed, and helped operate complicated anti-aircraft weaponry) should be held accountable for its role in the downing of Malaysia Airlines Flight 17, as a matter of public international law. If a nation-state, or its proxies, are responsible for the downing of civilian aircraft with military weaponry, and current international law does not provide a clear remedy, which appears to be the case under existing international rules (and as delineated in the first half of this article), this article secondarily will examine and call for concrete revisions to existing international law (namely, revisions to either treaty

* Associate Professor and Department Chair, Department of Legal Studies, University of Central Florida (UCF). I would like to thank FIU Law Dean Alex Acosta for hosting and supporting such an important symposium at FIU and Professor Timothy Ravich (UCF) for organizing the event, encouraging me to explore a topic of interest at this symposium, and ultimately allowing my participation in this event. Finally, I wish to extend my sincere thanks to the entire FIU Law Review for facilitating such an amazing symposium and for the many courtesies and editorial assistances in bringing this article to publication in the FIU Law Review.

1 MH17 Malaysia Plane Crash in Ukraine: What We Know, BBC NEws (Sept. 9, 2014), http:// www.bbc.com/news/world-europe-28357880.

2 Alejandro Davila Fragoso, Families of Malaysia Airlines Victims Unlikely to Receive Compensation, MCCLATCHYDC (July 30, 2014), http://www.mcclatchydc.com/2014/07/30/234899/ families-of-malaysia-airlines.html; Augustine Ruzindana, Lessons from Aviation History of Tragic Passenger Airline Shoot Downs, THE DAILy MONITOR (July 25, 2014), http://www.monitor.co.ug/ OpEd/Commentary/Lessons-from-aviation-history-of-tragic/-/689364/2396448/-/14nl4uk/-/index.html.
\end{abstract}


law, or the formation of new customary international law by renewed state practices in this area done out of a sense of legal obligation (i.e., opinio juris).

Setting aside political issues and subsequent fallout, and with a few notable exceptions (e.g., U.S. in 1988 for downing Iranian Airbus 655 by a missile, and Libya in 1988 for downing Pan Am 103 by a planted bomb), nations have been able to avoid significant legal liability for their roles in using military force. For instance, shortly after the Malaysian airline shootdown, in articles well circulated on the internet, and titled with such captions as "Families of Malaysia Airlines victims unlikely to receive compensation" and "Lessons from Aviation History of Tragic Passenger Airline Shoot Downs," many authors lamented the delineated long, relatively sordid history of nations attempting to avoid legal liability in such circumstances in the post-World War II era. ${ }^{3}$ Over time, and under both domestic and international law, the most predominantly responsible participants (and deep pocket defendants, if you will) have been the individual airline companies themselves. ${ }^{4}$ Phrased differently, even if a nation is responsible for downing a plane, often airlines (and insurance companies) are still left being legally liable and "holding the bag" under international laws, such as the Montreal Convention of 2003 and its predecessor operative treaty, the Warsaw Convention of $1933 .{ }^{5}$ Thus, in the infamous downing of KAL 007 by the Soviet Union in 1983, the Soviet Union, and, upon its dissolution, Russia were able to almost completely avoid any adverse financial "punishment" for their actions, while the airline (and its insurers) ultimately had to pay out several billions of dollars in damages to the grieved surviving family members. ${ }^{6}$ Thus, the ultimate goal of this article is to serve as a call for revisions to international law (ideally in the form of new treaty law through the amendment of an existing treaty) that would set forth clear positivist rules of international law that not only expressly delineate the repugnant nature of nation-state involvement in catastrophic air disasters, but also provide a strict set of compensation rules (including the imposition of punitive damages) for violations of these new rules. In essence, this article is a policy "reformation" or "advocacy" piece and a call for revisions to existing public international law governing nation-states, rather than an analysis or call for a revision of private

\footnotetext{
Fragoso, supra note 2.

GEORGE LELOUDAS, RISK AND LIABILITY IN AIR LAW 80 (2d ed. 2013).

5 Jonathan M. Stern, Cleared Direct to Federal Court: A Comprehensive Look at Jurisdiction and Removal, 48 FOR THE DEFENSE 56, 59 (2006).

6 Margalit Fox, Hans Ephraimson-Abt, Air Crash Victims' Crusader, Dies at 91, N.Y. TIMES (Oct. 26, 2013), http://www.nytimes.com/2013/10/27/us/hans-ephraimson-abt-air-crash-victimscrusader-dies-at-91.html?_r $=0$.
} 
international law (e.g., revisions to treaties such as the Montreal Convention of 2003 governing the liability of private corporations and actors other than nation-states). This article, however, does not examine U.S. domestic regulations, cases, or statutes covering typical aviation liability cases. ${ }^{7}$ Thus, within the confines of this article, I will not attempt the analysis of the nuances of current domestic aviation laws and recent cases, but instead will be arguing for a new set of international legal rules in this area. In so doing, this article will be pulling together important sources of international law, ranging from treaty law provisions (particularly the seminal Chicago Aviation Convention of 1944$)^{8}$ to customary law and general principles of international law, to several International Court of Justice (ICJ) decisions, ICJ jurisdictional issues, as well as references to U.S. domestic law (to be used by analogy and extension to the international legal regime). ${ }^{9}$

\section{BRIEF OVERVIEW AND ADDITIONAL INTRODUCTION}

While legal remedies for tortious conduct via international air travel are well known and have been much discussed in legal literature, particularly the application of the Warsaw Convention, ${ }^{10}$ the IATA Intercarrier Agreement on Passenger Liability, ${ }^{11}$ the Montreal Convention, ${ }^{12}$

7 For an excellent resource in this area, see generally PAUL S. DEMPSEY, AVIATION LiABILITY LAW (2d ed. 2013).

8 Convention on International Civil Aviation, Dec. 7, 1944, 61 Stat. 1180, 15 U.N.T.S. 295 [hereinafter Chicago Convention].

9 While I ultimately come to different conclusions and different points about international law and this issue of international law obligations (or lack thereof) of shooting down a civilian aircraft by a nation-state, I am indebted to the authors of two excellent earlier law review articles on this general topic. Specifically, a colleague of mine, John Phelps (whose career and military service overlapped with mine when we were both U.S. Army active duty judge advocates assigned to the U.S. Military Academy at West Point from 1994-1996), wrote an excellent "older" article on the topic in 1985. See John T. Phelps, Contemporary International Legal Issues-Aerial Intrusions by Civil and Military Aircraft in Time of Peace, 107 MIL. L. REv. 255, 288-90 (1985). Second, I am indebted to a fellow Georgetown Law Center alumnus, Brian E. Foont, who wrote a much more recent article exploring the nuisances and gaps of international law on this topical area. See Brian E. Foont, Shooting Down Civilian Aircraft: Is There an International Law?, 72 J. AIR L. \& COM. 4 (2007). While my proposed solutions and analysis diverge from both authors at key points, and while my conclusions differ, both articles remain sound and helpful resources for readers interested in pursuing this topical area.

10 Convention for the Unification of Certain Rules Relating to International Carriage by Air, Oct. 12, 1929, 49 Stat. 3000, 137 L.N.T.S. 11 [hereinafter Warsaw Convention]. The Warsaw Convention became effective with the requisite number of member state ratifications on February 13, 1933. As of 2014, the Warsaw Convention was ratified by 152 nations and ultimately governed claims of damage for death or other bodily damage on board international air travel until the Warsaw Convention compensation regime was replaced by the Montreal Convention, which was signed in 1999 and became effective in 2003.

11 International Air Transport Association, Intercarrier Agreement on Passenger Liability, open for signature Oct. 31, 1995, reprinted in LAWRENCE B. GOLDHIRSCH, THE WARSAW CONVENTION ANNOTATED: A LegAL HANDBOOK 577-78 (Kluwer Law International 2000) (1988). The IATA Intercarrier Agreement on Passenger Liability was a proposed agreement among private air carriers to 
and other such agreements and laws, ${ }^{13}$ this article argues for a different principle and set of rules and laws governing nation-state liability. Additionally, where a nation-state is the tortious actor (in the U.S. court system), the application of federal statutes such as the Foreign Sovereign Immunity Act and the Federal Tort Claims Act are also well known and well documented in cases and the literature. ${ }^{14}$ Although I, as well as many other authors, have addressed issues pertaining to the interplay between U.S. domestic laws, like the Federal Tort Claims Act and the Foreign Sovereign Immunity Act and international law, ${ }^{15}$ this article focuses on examining a different aspect of legal remedies for incidents of liability in the international airspace, namely the legal responsibility and liability of nation-states who directly or indirectly contribute to air catastrophes as a matter of international law.

This article will first call for important revisions to existing international law, namely through an amendment to the existing language of Article 3 bis of the Chicago Convention. Secondly, this article also calls for the recognition of the formation of new rules of customary international law in cases where the nation-state has direct or indirect involvement in sponsoring or supporting the private actors contributing to a catastrophic airline disaster. The article then calls for International Court of Justice

voluntarily waive the limits of liability contained in the Warsaw Convention (specifically Article 22, para. 1) as to claims of death and damages for other wounding and bodily injuries inflicted upon passengers during flight. The underlying purpose was meant to voluntary increase (or waive) the $\$ 75,000$ limitation imposed by the Warsaw Convention at that time.

12 Convention for the Unification of Certain Rules for International Carriage by Air, May 28, 1999, 2242 U.N.T.S. 350 [hereinafter Montreal Convention]. The Montreal Convention, not to be confused with the Montreal Convention of 1971, became effective with the requisite number of member state ratifications on November 4, 2003. As of 2014, 107 states are members, including the European Union as a signatory member. The Montreal Convention was meant to replace the Warsaw Convention compensation, which was deemed antiquated and obsolete by the end of the twentieth century. It replaced key parts of the Warsaw system (such as having to prove "willful misconduct" by the airline/air carrier in order to obtain more than $\$ 75,000$ in damages) and introduced a new two-tier liability system (enabling automatic damages from wrongful death cases in an amount of approximately $\$ 175,800$ per passenger by 2012 and the ability to prove damages in excess of this amount, if circumstances so dictate).

13 Other notable agreements or laws (not covered in this article) include such items as the IATA Agreement on Measures to Implement the IATA Intercarrier Agreement on Passenger Liability (known by the acronym "MIA") and the Air Transportation Association (ATA) of America's "ATA Intercarrier Agreement" (known by the acronym "IPA") and more formally titled "Provisions Implementing the IATA Intercarrier Agreement to be Included in Conditions of Carriage and Tariff." The purpose of this agreement was to further implement and operationalize the IATA Intercarrier Agreement in North America.

14 Phillip J. Kolczynski, Recent Developments in Airline Disaster Law, AvweB (Nov. 6, 2001), $\mathrm{http}: / /$ www.avweb.com/news/avlaw/181903-1.html\#FSIA; see also Stern, supra note 5, at 61-62.

15 See, e.g., James Beckman, Citizens Without a Forum: The Lack of an Appropriate and Consistent Remedy for United States Citizens Injured or Killed as a Result of Activity Above the Territorial Air Space, 22 B.C. INT'L \& COMP. L. REV. 249, $249-78$ (1999). 
adjudication of these disputes (in addition to the standard compensation schemes already in place against airliners and other third parties under laws such as the Montreal Convention of 2003) and for it to award more appropriate levels of damages against a nation, similar to the American legal systems notion of "punitive damages" for egregious harms inflicted. Finally, this article calls for revisions to Article 3 bis to include incidents where the application of military force on civilian airliners is by a nationstate itself, or through its agents and proxies and argues that the only exception or defense to Article 3 bis violations should be vis-à-vis a rigid and correct application of Article 51 of the United Nations (U.N.) Charters (for cases of clear, needed, and uncontested acts of self-defense by the nation-state). Again, to be clear, this article does not discuss the current compensation scheme and legal regime in place to typically handle international airplane disasters, or current cases (and/or current legal controversies) regarding the application of the Montreal Convention compensation scheme (or, for example, tort litigation in the United States). The focus of this article is exclusively a nation's responsibility under international law, and what legal remedies should be in place against that nation for the application of military force against a civilian aircraft.

In leading up to an analysis of the current set of rules (or lack thereof) in the public international law context, a summary of previous major cases involving nations and the use of military force against an aircraft is of value. A summary is of value both as an illustration of how these cases were handled (in terms of nation-state responsibility) and also how several of these cases have informed and impacted the evolution of the current international rules in place (most relevantly, Article 3 bis of the Chicago Convention). Finally, a summary is of value in illustrating how several cases might be applicable as valuable precedent in again revising the rules and also serving as a model for more appropriate levels of compensation for wrong-doing. Thus, Part I of the article will discuss nine major cases since the end of World War II, wherein a nation-state was directly or indirectly responsible for shooting an airplane out of the air, including the following cases: (1) the shooting down of a Cathay Pacific airliner (DC-4) off the coast of Hainan Island by China in 1954; (2) the shooting down of an Israel state owned aircraft (El Al Flight 402) by Bulgaria in 1955; (3) the shooting down of Libyan Arab Airlines Flight 114 by Israel in 1973; (4) the shooting down of Itavia Airlines Flight 870 in 1980 by an errantly fired missile by an undetermined country; ${ }^{16}(5)$ the shooting down of a Korean Airlines (KAL)

16 As of the date of this article, arguments persist as to which nation was responsible for firing the missile that downed this aircraft. Leading theories have suggested that the missile was shot from a French military jet or one operating under the auspices of the North Atlantic Treaty Organization (NATO) during NATO exercises occurring at that time. 
flight 007 by the then-Soviet Union in 1983; (6) the shooting down of Iranian Air Bus (Iran Air Flight 655) by the United States in 1988; (7) the bombing and downing of Pan Am Flight 103 (the "Lockerbie" flight) by two alleged agents of Libya in 1988; (8) the 2001 downing of Siberian Airlines Flight 1812 by Ukraine; and (9) the shooting down of a Malaysia airlines flight (Malaysia Airlines Flight 17) by Ukraine separatist/rebels (with alleged sponsorship from Russia) in 2014. ${ }^{17}$ The author has chosen the above nine examples for discussion as these are the most significant incidents since the end of World War II, wherein a nation-state attacked a civilian aircraft transporting civilian occupants only. Phrased another way, one country striking down another military plane is not within the scope of this paper. ${ }^{18}$ Thus, specifically excluded from this analysis then, for example, is the August 9, 1946, shoot down of an unarmed United States military transport plane (a C-47) traveling from Vienna to Italy. ${ }^{19}$ Therefore, for purposes of this article, in the post-World War II era, the first major case to be discussed below is the 1954 Cathay Pacific Airline shootdown by China.

Also omitted from this analysis are planes that are shot down by a nation-state when there are less than five civilian casualties. Admittedly, omitting airline causalities of less than five civilian causalities is an artificial distinction. However, the intention and rationale for the methodology of this approach is to eliminate those instances in which both military and civilian individuals are flying aboard a plane (or the civilian traveling aboard the plane is incident to the overall mission of the plane at issue). Additionally, this paper is most concerned with catastrophic loss of life at the hands of a nation-state, and not incidents where a plane might be shot and disabled, but ultimately is able to safely land without the catastrophic loss of life. Consequently, then, and again by way of example, the April 29, 1952, incident involving MiG-15 fighters from the Soviet Union attacking a French commercial airliner traveling from West Germany to West Berlin is also omitted from this study given the fortunate lack of large loss of life (and despite the aircraft being hit by 89 bullets by the Soviet MiG). ${ }^{20}$ This incident is omitted primarily because the airline landed safely and successfully, with only minimum damage and injury to only two

17 The reader will find articles referencing the facts of each of these incidents when each case example is referenced infra in this article.

18 There is a separate body of cases and laws involving the downing of unarmed military aircraft, which is beyond the scope of this article. For more information on this issue, see Phelps, supra note 9, at 266-72 and Foont, supra note 9, at 698-701.

19 See, e.g., Oliver J. Lissitzyn, The Treatment of Aerial Intruders in Recent Practice and International Law, 47 AM. J. INT'L L. 559, 569-70; see also Foont, supra note 9, at 700-01.

20 MARC DierikX, Clipping The Clouds: How Air TRAVEL CHANGED THE WORLd 44 (2008). 
of its passengers. ${ }^{21}$ Finally, an incident (the downing of a Korean Airlines Passenger Jet Flight 902), which was remarkably similar to a major incident analyzed in this paper (the 1983 downing of KAL007), is also excluded from this paper. While the facts are eerily similar, ${ }^{22}$ the 1978 incident is also omitted from this analysis because of the ultimate lack of the catastrophic loss of life involved in the 1978 incident. $^{23}$ While both airlines were attacked and fired upon by Soviet fighters, KAL 902 was able to navigate a landing, thereby ensuring the safety of ninety-five of the ninety-seven passengers ${ }^{24}$ and unlike the horrific downing of Flight KAL 007 several years later, ${ }^{25}$ the Soviet Union offered no compensation to the airline or surviving family members of the two individuals who did perish as a result of the crash landing. ${ }^{26}$

It is interesting to note, even all of these cases referenced above that are excluded from this study, the involved nations in each instance denied any legal responsibility or any legal obligation to make compensation or reparations for damages caused by its actions in each instance or case. This is consistent with the approach several nations (discussed infra) have taken in shooting down civilian aircrafts as well. While in some instances (of the nine cases discussed below), some nations provided compensation, while others did not. ${ }^{27}$ Additionally, as the reader will see, when payment was provided, it was provided with a clear disclaimer by the country that such payment was not being afforded because it was legally obligated to do so. Thus, as part of the discussion of these nine major cases in Part I, an analysis of how next of kin and parties were compensated in each of the cases will be referenced. Each of these incidents arguably involved separate compensation schemes or approaches, and the nation-states rationale or reasons for making such payments, or not making them at all.

Part II of the article will then discuss the basic concepts of international law in place at present governing national state responsibility in this area. The analysis in this section will include a discussion of Article 3 bis of the Chicago Convention, Article 51 of the U.N. Charter, customary international law norms (if any) and whether the prohibition on utilizing

$21 \quad I d$.

22 Both instances involved Korean Airlines flying from Anchorage, Alaska, and then over Soviet Airspace, before being attacked by Russian fighter planes - and are separated in time by only five years.

23 The Worst, But Not the First, Time Magazine, Sept. 12, 1983, at 21.

24 Indeed, of the ninety-seven passengers and crew, only two perished during the emergency landing on a frozen lake in rural Russia.

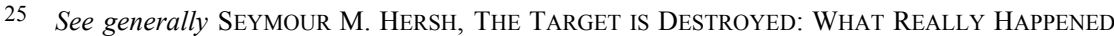
TO FLIGHT 007 AND WHAT AMERICA KNEW ABOUT IT (1986).

26 Id. at 8.

27 Paul B. Larsen, Aviation Law: CASES, LAws AND Related SOURCES 43-44 (John Gillick \& Joseph C. Sweeney eds., 2d ed. 2012). 
military force on civilian airliners has arisen to the level of a Jus Cogens, or preemptory norm violation. This section of the article will also discuss existing remedies in place to pursue damages and problems with the current state of international law in this area, making such claims difficult at present.

Part III of this article will then call for revisions to existing treaty law, or that at least cogent and strong customary international law arguments can be put forth for the application of significant and meaningful damages as a means of appropriately punishing the nation for egregious wrong doing, as well as appropriate compensation. As part of the analysis of adequate compensation vis-à-vis a nation-state, this article will briefly explore and explain the concept of punitive damages in the U.S. domestic legal system, including why the concepts or doctrines exist and what the doctrines are meant to achieve in the U.S. legal system. This article calls for the same level of liability of the nation-state, a position supportable by several International Court of Justice decisions, as well as emerging law in certain domestic jurisdictions. ${ }^{28}$

Finally, the concluding portion of this article will culminate with a call for revisions to current public international rules regarding nation-state complicity for airline disasters. Because of the horrific nature and loss of life involved in airplanes shot down, and because of the absolute power of a nation-state on the international plane, punitive damages should be applied to these cases, regardless of whether the nation-state's involvement is direct or indirect. ${ }^{29}$

\section{PART I: MAJOR INCIDENTS OF STATE-SPONSORED UTILIZATION OF MiLITARY ForCE UPON CIVILIAN AIRCRAFT (IN CHRONOLOGICAL ORDER POST-WORLD WAR II)}

Utilizing the methodology delineated above, there are nine major incidents involving the downing of civilian airliners (with corresponding

28 For instance, in the United States, while punitive damages typically have not been applicable for actors found liable through a vicarious liability theory, U.S. case law has started to emerge allowing for the merger of these two doctrines. See, e.g., Mercury Motors Exp., Inc. v. Smith, 393 So. 2 d 545 (Fla. 1981) (finding that an employer could be held liable in punitive damages, and through the application of vicarious liability, for the willful and wanton misconduct of its employee while acting within the scope of his employment). In the unique category of airline disasters (given the catastrophic loss of life), this article will call for the same doctrines to be adopted and applied as a matter of public international law amongst nation-states.

29 That is, there should be nation-state responsibility regardless of the whether the country conducted the actions directly through state sponsored actors, like in the case of bombing of the Pan Am 103 Lockerbie flight in 1989 by state agents, or by indirect involvement with rebels or other paramilitary organizations, which enables those "organizations" to then utilize military force against a civilian aircraft. 
catastrophic loss of life) by military force employed by a nation-state. There is an abundance of literature too numerous to delineate here on all of the below nine cases, including contemporary news accounts and several full length books. As such, the full factual details and accounts of all of the incidents below will not be recounted again here. The purpose of discussing these cases is not to comprehensively and exhaustively discuss each of the incidents, but rather to provide brief summaries of each of the nine instances for the reader's use in working through the international laws discussed in the second half of this article.

\section{The 1954 Cathay Pacific Incident}

On July 23, 1954, a Cathay Pacific Airways C-54 Skymaster (Douglas DC-4) was shot down by the People's Republic of China ("PRC") over the coast of the Hainan Island. ${ }^{30}$ The plane's intended course of travel was from Bangkok to Hong Kong. ${ }^{31}$ Ten of the nineteen passengers onboard the plane were killed. ${ }^{32}$ While it was technically a military plane, it was flying a commercial passenger run at the time it was shot down by Chinese pilots. ${ }^{33}$ For the first four hours and twenty-five minutes, the trip was uneventful. ${ }^{34}$ Then, while cruising at 9,000 feet and only thirty-one miles from Hong Kong, two Chinese fighter plans (from the People's Liberation Army Air Force) appeared on both sides of the rear of the plane, firing multiple rounds into the outboard engines, disabling several engines. ${ }^{35}$ The Chinese fighter planes continued to fire shots into the plane as it lost altitude, and the plane's pilots tried desperately to engage in evasive action. ${ }^{36}$ So aggressive were the Chinese fighter pilots that they continued to fire at the distressed plane until the disabled plane impacted with the water. ${ }^{37}$ In fact, many of the surviving passengers hid under plane debris in fear of the pilots returning to kill innocent victims still alive in the water. ${ }^{38}$

The official position from Communist China was that the plane was mistaken as a Chinese Nationalist military plane en route to attack a

30 Multiple accounts of this incident can be found in various sources, including the following: Peter Thacher, Incident on the China Coast, READER's Digest, Nov. 1954, at 14-22; Red China: A 'Kill' off Hainan, NewsweEK, Aug. 2, 1954; China Seas, Time, Aug. 2, 1954; VR-HEU Account by Passenger Valerie Parish, (July 23, 1954), available at http://dnausers.d-n-a.net/dnetGOjg/230754.htm.

31 Phelps, supra note 9, at 277.

32 VR-HEU Account by Passenger Valerie Parish, supra note 30, at 1.

33 Foont, supra note 9, at 705

34 VR-HEU Account by Passenger Valerie Parish, supra note 30, at 1.

35 Id.

36 Id

37 Id

38 Id. 
military base at Port Yulin on Hainan Island. ${ }^{39}$ Several competing theories speculated that perhaps the plane was attacked because it was transporting a high ranking Chinese Nationalist official, or even that it may have been transporting United States Ambassador to Thailand, "Wild Bill" Donovon (who was also head of the OSS in World War Two and the early inspiration for what became the Central Intelligence Agency). ${ }^{40}$

The political aftermath was a disaster for the PRC. Both Britain and the United States condemned the attack in the sharpest terms, demanding that the Chinese regime be held politically and financially responsible. ${ }^{41}$ Compensation for the victims' families and their survivors came quicker than otherwise might have been expected, as the incident was a major embarrassment for the government in Peking, and it seriously diminished the likelihood of the PRC being admitted to the still relatively new United Nations. ${ }^{42}$ In fact, several U.S. Senators and Congressman gave speeches citing the Cathay Pacific Douglas shoot-down as grounds for opposing the PRC's admittance to the United Nations. ${ }^{43}$

Thus, within three days of the incident, the PRC admitted responsibility by rendering a public apology, stating that its actions were an unwarranted attack against civilians ${ }^{44}$ and privately compensated the Cathay Pacific Airlines and the victims of the incident. ${ }^{45}$ The compensation made to the victims was not pursuant to a set of legal rules, rather through diplomatic negotiations. ${ }^{46}$ According to the Chicago Tribune, the British government made a demand to communist China for $\$ 1,030,000 .^{47}$ This claim was to cover all claims of the passengers and crew (deceased and alive), irrespective of nationality, as well as Cathay Pacific's claims for the

39 Id.

40 These theories stemmed from a 1940 article which referenced other potential occupants to the Cathay Pacific Flight that the Communist Chinese thought might be onboard the aircraft. See Jack T. Woodyard, We Rescued the Victims of Red China's Murder Planes, SATURDAY EvEnING Post, Oct. 23, 1954, at 22; see also GAVIN YounG, BEYOND LiON Rock: THE STORY OF CATHAY PACIFIC AIRLINES ch. 10 (Faber \& Faber 2012).

41 Id.

42 CPA Airliner Outrage, SouTh ChInA MORNING POST, July 26, 1954.

43 Id.

44 Hong Kong-Plane Survivors, MOVIETONE NEws (1954), available at http://www.movietone. com/assets/BMN0938/wmv/CSAI128371CSAIEND_CSEXT61543CSEXTEND_H.wmv.

45 Chinese Reds Apologize for Plane Attack, Desert Times SAlt LAKE TElegram, July 26, 1954, at A1-A2, available at https://news.google.com/newspapers?nid=336\&dat=19540726\&id= holaAAAAIBAJ\&sjid=90kDAAAAIBAJ\&pg=5814,3922841\&hl=en.

46 U.S. Dept. of State, No. 241 Memorandum of Conversation from the Director of the Office of Chinese Affairs (McConaughy), XIV FOREIGN RELATIONS OF THE UNITED STATES 1952-1954 CHINA AND JAPAN 508-09, July 26, 1954, available at http://history.state.gov/historicaldocuments/frus 1952$54 \mathrm{v} 14 \mathrm{p} 1 / \mathrm{d} 241$.

47 British Ask Peiping to Pay \$1,030,000 for Loss of Plane, CHICAGO TRIBUNE, Sep. 16, 1954. 
property damage it suffered. ${ }^{48}$ In a secret meeting between British and American officials about the incident, it was decided that it would be "preferable for the British Government to handle all indemnity claims" through its "good offices," as the British believed that they "might be able to get compensation for all the cases, including the American ones if the matter were handled entirely by the British." ${ }^{, 49}$ The group further believed that they "would get a "dusty answer" if the claim for damages was presented by the Americans. ${ }^{50}$ Ultimately, the British presented a demand to the Chinese- $£ 367,000$ for "benefits and compensation for all involved"and required that China agree to this settlement amount. ${ }^{51}$ This compensation was further divided among claimants from the United States, Britain, Australia, and Portugal, and it also included the "loss of freight and baggage expenses incurred by the British Cathay Pacific Airways Company." 52

\section{The 1955 Shoot-down of the Israeli El Al by Bulgaria}

Bulgarian fighter jets shot down the State of Israel's then-national airline, El Al (Flight 402), on July 27, 1955, as it made its way from Vienna, Austria to Tel Aviv, Israel. ${ }^{53}$ When the plane unintentionally strayed into Bulgarian airspace, it was ordered to land at a military airbase outside of Sofia, Bulgaria's capital. ${ }^{54}$ While the civilian airplane complied and attempted to make its way to the airbase, it nevertheless came under fire by Bulgarian MiG fighter jets. ${ }^{55}$ As a result, the plane crashed, resulting in the loss of fifty-eight occupants of the plane (all fifty-one passengers and seven crew members). ${ }^{56}$ In the ensuing days, the Bulgarian version of events changed several times. ${ }^{57}$ First, Bulgaria claimed it shot down the plane because it could not be identified (and therefore might be a military plane by implication). ${ }^{58}$ Several days later, Bulgaria changed its claim and

\section{Id}

49 Memorandum of Conversation from the Director of the Office of Chinese Affairs (McConaughy), supra note 46, at 508.

50 Id.

51 Cathay Pacific Airways (Compensation from China), 532 Written Answers (Commons) c58W, Nov. 3, 1954, available at http://hansard.millbanksystems.com/written_answers/1954/nov/03/cathaypacific-airways-compensation-from; see also China to Pay Compensation, THE NAMBOUR CHRONICLE AND NorTh COAST ADVERTISER, Nov. 5, 1954, at 9.

52 Britain to Share Compensation, THE CANBERRA TIMES, Dec. 30, 1954, at 2.

53 Phelps, supra note 9, at 279.

54 Id.

55 Id

56 Id

$57 \quad I d$

58 Id. 
admitted that it knew the plane was a civilian aircraft, but shot it down when the pilot allegedly refused instructions to land ${ }^{59}$ Finally, a few days later, Bulgaria changed its position again, and offered to make "ex gratia" payments for damages, ${ }^{60}$ while still denying all legal responsibility (or the legal obligation to pay for the damage to life and property). ${ }^{61}$ The "ex gratia" payment amounted to a payment of $\$ 195,000$ to Israel, ${ }^{62}$ which excluded non-Israeli passengers already compensated from the United States, the United Kingdom, Sweden and several other nationalities. ${ }^{63}$ Israel did attempt to sue Bulgaria in the ICJ on October 16, 1957, but the ICJ dismissed the case for want of jurisdiction, as the ICJ ruled that it did not have compulsory jurisdiction ${ }^{64}$ over Bulgaria as a defendant in the case. ${ }^{65}$ At least one author has claimed that Israel denied the attempt at compensation by Bulgaria as too low. ${ }^{66}$

\section{The 1973 Shoot-down of Libyan Airlines Passenger Jet by Israel}

The first major incident involving the catastrophic and large loss of civilian life at the hands of a nation-state occurred on February 21, $1973 .{ }^{67}$ A Libyan airliner was admittedly over one-hundred miles off course and

59 Id.

60 Abraham D. Sofaer, Compensation for Iranian Airbus Tragedy, 88 Dep't of St. Bull., Oct. 1988 , at 58 .

61 Marvin G. Goldman, El Al: StAR IN THE SKY, at 149(1990); see also Phelps, supra note 9, at $276-77,79$.

62 See Ruzindana, supra note 2, at 1.

63 Phelps, supra note 9, at 279.

64 Every member of the United Nations is ipso facto a member of the International Court of Justice and bound by the Statute of the International Court of Justice. See U.N. Charter art. 93. However, being "ipso facto parties to the Statute of the International Court of Justice," does not mean that the ICJ actually has jurisdiction over a case involving a particular country in every possible instance. Rather, the ICJ only has jurisdiction over those cases as spelled out in Article 36 of the Statute of the International Court of Justice. Under Article 36(1), those jurisdictional grounds include "all cases which the parties refer to it and all matters specially provided for in the Charter of the United Nations or in treaties and conventions in force." Absent cases referred to the Court by both countries, or being joint members of an applicable treaty that calls for ICJ jurisdiction, the only other way is if a country has accepted the socalled "compulsory jurisdiction" under Article 36(2). Article 36(2) specifies that "state parties to the present Statute may at any time declare that they recognize as compulsory ipso facto and without special agreement, in relation to any other state accepting the same obligation, the jurisdiction of the Court in all legal disputes concerning: the interpretation of a treaty; any question of international law; the existence of any fact which, if established, would constitute a breach of an international obligation; or the nature or extent of the reparation to be made for the breach of an international obligation." As there was no applicable treaty between Bulgaria and Israel, and Bulgaria had not accepted the compulsory jurisdiction of the Court, the Court lacked jurisdiction to decide the case. Statute of the International Court of Justice art. 36(2), Apr. 18, 1946.

65 Aerial Incident of 27 July 1955 (Israel v. Bulgaria), 1959 I.C.J. 127 (May 26).

66 Fragoso, supra note 2.

67 Phelps, supra note 9, at 288; Foont, supra note 9, at 706. 
(according to the Israelis) over a sensitive military base at Bir Gafgfa. ${ }^{68}$ Israeli fighter pilots overtook the airliner and ordered the airliner to land. ${ }^{69}$ Despite these verbal orders, the Libyan pilots refused (despite later evidence that established that they had received the verbal instructions to land and intentionally decided to ignore the Israeli order).$^{70}$ As a result, the Israeli fighter planes fired on the civilian airliner, downing the plane, and killing 108 of the 113 passengers onboard. ${ }^{71}$ Many countries condemned the act. ${ }^{72}$ While Israel stoutly defended the propriety of its actions based upon multiple grounds, ultimately, while again insisting that it acted properly, Israel made "ex gratia" payments for damages, much like the Chinese (in the Cathay Pacific Incident of 1954 and the 1955 Bulgarian incidents before). ${ }^{73}$ The amount of the payments were undisclosed to the public. ${ }^{74}$

\section{Shoot-down of Itavia Airlines Flight 870}

This plane, which carried eighty-one passengers and crew members, crashed without warning near Palermo, Sicily. ${ }^{75}$ To this day, countries are arguing about why the flight crashed. ${ }^{76}$ An Italian Court judge (Rosario Priore) ruled that there was "clear evidence" that the plane was struck by a missile; however, there seems to be no similarly clear evidence as to which country was responsible for the missile strike, or why it would be launched in the first instance. ${ }^{77}$ The judge put forth the theory that perhaps the flight was shot down during an alleged NATO operation to down a plane carrying Libyan head of state Muammar Gaddafi. ${ }^{78}$ The Italian Prime Minister at the time of the incident, Francesco Cossiga, claimed that the plane was shot down by the French - but the French denied the claim (and the Italians themselves have also been blamed), and as late as 2015, liability has yet to

$68 I d$

69 Id

$70 \quad I d$

71 For a comprehensive description of the incident and Israel's legal response, see Phelps, supra note 9 , at 288-90.

72 Phelps, supra note 9, at 289.

73 Sofaer, supra note 60, at 58; see also Ruzindana, supra note 2, at 1.

74 Fragoso, supra note 2.

75 Alan Cowell, Italian Obsession: Was Airliner Shot Down?, N.Y. TIMES, Feb. 10, 1992; Italian DC-9 lost off Sicily, FLIGHT INTERNATIONAL, July 5, 1980), available at http://www.flightglobal.com/ FlightPDFArchive/1980/1980\%20-\%201610.PDF.

76 Cowell, supra note 75; see also Barbara McMahon, The Mystery of Flight 870, THE Guardian, July 21, 2006; Elisabetta Povoledo, Conspiracy Buffs Gain in Court Ruling on Crash, N.Y. TIMES, Feb. 10, 2013.

77 Italian Court: Missile caused 1980 Mediterranean Plane Crash; Italy Must Pay Compensation, Fox NEws, Jan. 28, 2013.

78 McMahon, supra note 76 , at 2. 
be established. ${ }^{79}$

\section{Shoot-down of Korean Airlines Flight 007}

Again, in facts eerily similar to the 1978 Soviet firing on Korean Airlines Flight 902 (which fortunately resulted in the loss of only two lives out of ninety-seven passengers), the 269 crew members and passengers of a Korean Airlines Flight 007 were not as fortunate. ${ }^{80}$ In one of the infamous incidents of shooting down an aircraft by a nation-state, on September 1, 1983, Soviet fighter jets fired at and completely destroyed Korean Airlines Flight 007 but only after the disabled plane "entered into a controlled spiral descent that lasted for about 12 minutes [and] during which time the passengers were alive" ${ }^{" 11}$ until the plane slammed into the international waters of the Sea of Japan (off the coast of Siberia and close to Sakhalin Island). ${ }^{82}$ This flight originated in New York, re-fueled in Anchorage (like Korean Flight 902 five years before) and was fired on by Soviet jets when it veered into Soviet Airspace (again, like Flight 902). ${ }^{83}$ However, unlike Korean Flight 902, which was able to land in a relatively safe manner with only the loss of two individuals onboard, Korean Flight 007 perished over the skies of the Soviet Union, with all 269 passengers and crew members onboard also perishing in the plane's destruction. ${ }^{84}$ Initially the Soviet Union denied even knowing about the incident, despite the fact that Soviet fighter jets had tracked the civilian airliner for several hours. ${ }^{85}$ Despite world condemnation and sanctions by many countries, the Soviet Union denied legal responsibility, claiming that the airline had violated Soviet airspace and, therefore, violated its territorial sovereignty. ${ }^{86}$ The Soviets even insisted for years that the plane might have been on a spy mission, ${ }^{87}$ or that the United States was testing the Soviet's air defense systems. ${ }^{88}$

The Soviets also denied any liability or legal responsibility for the

79 Id.

80 Legal Argumentation in International Crises: The Downing of Korean Air Lines Flight 007, 97 HARV. L. REV. 1198 (1984).

81 Court to Hear KAL 007 'Pain and Suffering' Claim, CNN INTERACTIVE (Apr. 27, 1998, 10:47 AM), http://www.cnn.com/US/9804/27/scotus.kal.shoot/.

82 Fox, supra note 6. As the article points out, the transcript of the voice recorder for KAL 007, finally turned over to victims' families by Boris Yeltsin only in 1992, revealed that the plane had in fact not exploded upon impact with two Soviet fighter missiles, but rather "remained aloft for some minutes before plunging into the sea."

83 Foont, supra note 9, at 707-708.

84 Phelps, supra note 9, at 256-257.

85 Id. at 266.

86 Id. at $257-258,261$.

87 Fox, supra note 6 (reporting in part that "[T]he Soviet Union long maintained that the flight was a spy plane sent by the United States").

88 Id. at 258. 
families of the victims. ${ }^{89}$ Despite demands from countries like South Korea, which were made for years afterwards,${ }^{90}$ the Soviet Union (and then, its predecessor state, Russia) would continue to deny legal responsibility well after the end of the cold-war. In fact, despite condemnation by the United Nations, the United States, and the International Civil Aviation Organization, the Soviets insisted on denying responsibility and deliberatively employed tactics designed to delay the investigation. For instance, the plane's black boxes were not even turned over to the United States until 1992 by Boris Yeltsin, almost a decade after the flight was downed, and a couple of years after the Soviet Union actually dissolved. It would be years until families received financial payments from Korean Airlines for the tragedy, and this happened only after the U.S. Supreme Court determined that the victims' families could receive pre-death pain and suffering compensation for KAL's "willful misconduct" by attempting to navigate through restricted Soviet Union airspace. ${ }^{91}$ In the end, after a long drawn out legal battle in the United States, ultimately culminating in an appeal to the Supreme Court, many of the families finally began receiving compensation-not from Russia, but from Korean Airlines. ${ }^{92}$ Thus, for example, in 1997, a federal jury awarded the surviving family members of a recent college graduate who had perished on board flight $902 \$ 2.1$ million in compensation. ${ }^{93}$ According to The New York Times and the Associated Press, out of court settlements for the surviving family members of other victims ranged from $\$ 75,000$ to $\$ 10$ million. ${ }^{94}$ One of the few long-term benefits of this tragedy is that it prompted President Reagan to make public the GPS technology needed to accurately guide and track planes.

89 George J. Church, The Price of Isolation, TIME, July 25, 1988, at 34.

90 Seoul to Demand Russian Compensation for KAL 007, AssocIATED PRESS (July 7, 1993, 12:24 AM), http://www.apnewsarchive.com/1993/Seoul-to-Demand-Russian-Compensation-for-KAL007/id-928a0852c7cb25c0f351514074153baf.

91 As an aside, the Supreme Court was not denying families pain and suffering damages under the Chicago Convention (Warsaw or IATA), rather the 1998 U.S. Supreme Court case had to do with the application of a 1996 ruling from the Court in interpreting a different law (namely, the "Death on the High Seas Act"). In the 1996 case, the Court had ruled that the "Death on the High Seas Act" did preclude relatives of deceased individuals from claiming non-economic damages (like pain and suffering). See Zickerman v. Korean Air Line Co., 516 U.S. 217 (1996). In the 1998 ruling, the Supreme Court ultimately distinguished the KAL 007 litigation from its previous 1996 ruling, thereby opening the door for significant claims of damages from families for the pain and suffering of the victims, as well as the pain and suffering of losing a loved one. The resulting settlements, some never completely disclosed, collectively ranged in the billions. Dooley v. Korean Air Lines Co., 524 U.S. 116 (1998).

92 Indeed, lawsuits against the Soviet Union (for actually shooting down the plane) and the United States (for failing to notify the Soviet Union that a civilian plane had veered off course into Soviet airspace) were quickly dismissed at the U.S. district court level. See, e.g., Richard K. Sypher, Seven Years Later, Flight 007 Families Wait for Payment, SEATtLe Times, Feb. 5, 1991.

93 See generally Fox, supra note 6.

94 See id. 


\section{Shoot-down of Iran Airlines Flight 655 by the United States}

On July 3, 1988, only five years after the destruction of KAL Flight 007, an act that the United States characterized as a "crime against humanity" that "must never be forgotten," 95 an American missile cruiser, the USS Vincennes, shot down a civilian airliner with two surface to air missiles. At the time it was shot down, the flight had approximately 290 passengers onboard. ${ }^{96}$ There were no survivors. The plane was "operating within its previously prescribed and published time and course patterns, [and] was intercepted and destroyed, within its own national airspace over its own national territorial waters." ${ }^{97}$ Although President Reagan and Vice President Bush called the event a "terrible tragedy," initially defended its actions in firing on the plane as an example of "proper defensive action." 99 The United States later sent a diplomatic note claiming that "a particularly heavy burden of responsibility rests with the government of Iran." Vice President Bush likewise asserted that any argument that the United States acted maliciously was "offensive and absurd." 100

Like the Soviet Union five years before, President Reagan never openly apologized for the United States' action on July 3, 1988. However, while the White House did intimate that it would make restitution at a very early date, that "restitution" did not occur until after the United States was sued by Iran in the ICJ. Only after ICJ "intervention" did the Clinton Administration finally agree, in 1996, to make payments in the approximate amount of $\$ 131$ million, with nearly $\$ 62$ million going to the families of the victims. ${ }^{101}$ This, as one author has stated, amounted to only " $1 / 30$ th of the

95 Ruzindana, supra note 2, at 1; see also Moments in U.S. Diplomatic History: The Downing of Flight KAL 007, Ass'n for Diplomatic Studies and Training, http://adst.org/2014/03/the-downing-of-kalflight-007/ (last accessed Oct. 19, 2015); and http://adst.org/2014/03/the-downing-of-kal-flight-007/.

96 Notably, Iran claimed that there were 290 passengers onboard the aircraft in its Application Instituting Proceedings filed with the International Criminal Court, although some sources differ slightly in the total number of passengers. Application Instituting Proceedings Regarding Aerial Incident of 3 July 1988 (Iran v. U.S.), 1989 I.C.J. Pleadings 79 (May 17).

97 Id

98 Associated Press, Jet Downing was a "Terrible Tragedy;" Bush Tells U.N.: Iran Calls U.S. Attack “Barbaric," L.A. TIMES (July 14, 1988), http://articles.latimes.com/1988-07-14/news/mn8944_1_iran-air; see also Ruzindana, supra note 2, at 1 .

99 Fragoso, supra note 2, at 1 (noting, in part, that the Vincennes was also simultaneously engaged in firefights with several Iranian gunboats in Iranian territorial waters).

100 Cathleen Decker, Bush Faults Iran Role in Air Disaster: Tehran Failed to Divert Plane from Area, He Tells U.N., L.A. TIMES (July 15, 1988), http://articles.latimes.com/1988-07-15/news/mn7187_1_iran-air; see also Ruzindana, supra note 2, at 1 .

101 Fred Kaplain, America's Flight 17: The time the United States blew up a passenger planeand tried to cover it up, SLATE, at http://www.slate.com/articles/news_and_politics/war_stories/2014/ 07/the_vincennes_downing_of_iran_air_flight_655_the_united_states_tried_to.html (last accessed Oct. 19, 2015). 
compensation the U.S. secured from Libya for the Lockerbie plane bombing."

\section{Destruction of Pan Am Flight 103 over Lockerbie, Scotland}

Pan American Airlines, or Pan Am Flight 103, was destroyed by a terrorist-planted-bomb while over Lockerbie, Scotland, en route from London to New York on December 21, 1988. The bomb killed all 243 passengers and 16 crew members on board. Large chunks of the plane crashed into the village of Lockerbie, Scotland, resulting in the deaths of eleven more individuals in the village (most oblivious to the impeding devastation plunging from the heavens above). It is included as one of the case studies here because of the clear state-sanctioned involvement (by Libya) that came out years after the bombing. Specifically, after a prolonged multi-year investigation by several prominent law enforcement organizations (including the United States' Federal Bureau of Investigation), it was determined by various law enforcement investigations that two Libyan operatives, Abdel Basset al-Megrahi and Al-Amin Khalifa Fahima, had planted the bomb on board the airplane. These two men were indicted, and arrest warrants were issued in 1991. ${ }^{103}$ After years of international pressure (and international and U.N. sanctions), the two individuals were turned over by Libya to stand trial in a special compound developed to handle the case, at Camp Zeist in the Netherlands. Of the two individuals, one (Fahima) was acquitted, and the other (Megrahi, a clearly documented Libyan operative) was convicted of the offense. ${ }^{104}$ The convicted individual, Megrahi, was finally jailed in 2001 and incarcerated in Scotland until August, 2009 (when he was released on "compassionate" grounds of being terminally ill with cancer; he died in May 2012). ${ }^{105}$

Finally, in 2003, Libya accepted responsibility for the Lockerbie bombing and paid compensation to the families of the victims. ${ }^{106}$ For the

102 Id.; Ruzindana, supra note 2, at 1.

103 James Cook, Lockerbie Questions Remain Following Megrahi's Death, BBC WORLD NeWs (May 20, 2012), http://www.bbc.com/news/uk-scotland-south-scotland-12191604.

104 Verdict of the Scottish Court in the Netherlands, OFFICIAL TRIAL TRANSCRIPT, at 10235-10237, http://i-p-o.org/Lockerbie_Verdict-31Jan2001.htm (last accessed on October 19, 2015).

105 Cook, supra note 103.

106 There is still is lingering debate as to whether Libya was sincere in accepting responsibility for the bombing, or that it was simply the result of a desire to lift years of debilitating sanctions upon Libya by the world community. The then head of Libya (Colonel Gaddafi) claimed he had never ordered the bombing, although this claim was contradicted by a high ranking government official in 2011, who claimed that the order to bomb the plane did emanate from Libya's head of state. Further, in a BBC Radio interview on February 24, 2004, the Libyan Prime Minister Shukri Ghanem stated that the payment was made as the "price of peace" and to ensure the lifting of sanctions. When pressed if Libya truly denied "guilt" for the bombing, Ghanem responded by saying "I agree with that." Mike Thomson, Libya's Prime Minister, Shuri Ghanem, Has Claimed that His Country Played No Part in Either the 
first time, a nation paid damages in an amount that might be properly considered akin to the concept of punitive damages. Specifically, on Friday, August 15, 2003, Libya sent a letter to the United Nations Security Council in which it "accept[ed] responsibility for the actions of its officials" and offered the unprecedented amount of $\$ 2.7$ billion dollars to settle all the claims by relatives of the deceased passengers onboard the flight. ${ }^{107}$ This amounted to payments of roughly $\$ 10$ million per family (with approximately 270 killed in the bombing). One of the lawyers who negotiated the final settlement described Libya's offer of payment as "unchartered waters... [as] it is the first time that any of the states designated as sponsors of terrorism have offered compensation to families of terror victims." ${ }^{108}$ In fact, the precedent set by this payment is the model, which, this author advocates, should be the appropriate type of compensation provided to members of air disasters caused by the application of military force by a nation - an amount quite akin to the notion of "punitive damages" in the American system, instead of merely more "nominal" sums based upon notions of just "compensatory" damages. Indeed, on August 22, 2003, Libya transferred \$2.7 billion into the Bank of International Settlements at Basel for future payments. ${ }^{109}$ The payments of $\$ 10$ million per family were to be dispensed in three stages: (1) coordinating with the lifting of sanctions by the United Nations against Libya, (2) the lifting of sanctions by the United States, and (3) the removal of Libya off of the United States list "state sponsors of terrorism." 110 Two of the three conditions or stages were met for compensation, but one condition was not met, meaning each family ultimately received $\$ 8$ million, instead of the full $\$ 10$ million originally promised. ${ }^{111}$ While not directly

Lockerbie Bombing or the Shooting of WPC Yvonne Fletcher, BBC HOME (Feb. 24, 2004), http:// www.bbc.co.uk/radio4/today/reports/misc/libya_20040224.shtml.

107 Peter Slevin, Libya Takes Blame for Lockerbie Bombing, WASH. Post, Aug. 16, 2003, at A1; see also SEAN Murphy, United StATes Practice IN InTERnATIONAL LAw Vol. 2: 2002-2004, 372 (Cambridge Univ. Press, 2005).

108 Matthew L. Wald, Libya Offers \$2.7 Billion Lockerbie Settlement, CHI. TRIB. (May 29, 2002), http://articles.chicagotribune.com/2002-05-29/news/0205290418_1_britain-and-libya-united-nationssanctions-terrorism.

109 Philip T. Reeker, U.S. Department of State Daily Press Briefing, www.STATE.Gov (Aug. 25, 2003), http://www.state.gov/dpbarchive/2003/23528.htm.

110 These three stages were that the first $\$ 4$ million (of the total $\$ 10$ million) per family was to be dispensed upon the lifting of United Nations sanctions, the second $\$ 4$ million per family was to be dispensed upon the lifting of United States sanctions, and the final \$2 million per family was to be dispensed upon the removal of Libya from the U.S. listing of those nations designated as "sponsors of state terrorism." Libyan Payment to Families of Pan Am Flight 103 Victims, 97 AM. J. INT'L L. LAW, 987, 990 (2003); see also Murphy, supra note 107, at 372.

111 As discussed in the previous footnote, the final \$2 million in payments for each of the 270 families was predicated upon the United States removing Libya from its list of "state sponsored terrorist states." However, because the United States did not remove Libya from the U.S. State department list 
germane to this article, it should be noted that a civil action was maintained by Pan Am and its insurers for another $\$ 4.5$ billion in damages, until the suit was discontinued in February 2005.

\section{Shoot-down of Flight 1812}

Siberian Airlines Flight (1812), travelling from Tel Aviv to Novosibirsk was downed by a Ukrainian missile, killing seventy-eight passengers. ${ }^{112}$ Like many other incidents discussed in this section, Ukraine initially denied responsibility. ${ }^{113}$ However, after being presented with U.S. satellite imaging, proving that a Ukrainian long-range missile shot down the plane, ${ }^{114}$ President Kuchma admitted that the Ukraine was at fault and promised that it would appropriately compensate the families. Ukraine eventually paid $\$ 15.6$ million. ${ }^{115}$ Per an agreement with Israel in 2003, Ukraine paid $\$ 200,000$ to the family of each victim from Israel killed in the accident (a total of forty Israel citizens perished onboard). ${ }^{116}$ Likewise, per an agreement with Russia in 2004, Ukraine agreed to pay $\$ 200,000$ to the family of each victim from Russia (a total of thirty-eight Russians perished onboard).

\section{Malaysian Airlines Flight 17 Incident}

The flight was en route from Amsterdam to Kuala Lumpur, and contained 298 passengers and crew, when it crashed on July 17, 2014, over separatist rebel held territory in eastern Russia. Investigations have suggested that the flight was "likely struck by multiple "high-energy objects from outside the aircraft,' causing it to break up." 117 Initial reports suggested that the plane instantly disintegrated at about 33,000 feet after being hit by high velocity shrapnel. However, it is possible that the plane

before the agreed upon deadline, Libya had the final $\$ 540$ million that it had originally deposited in August 2003 withdrawn from the account and re-deposited in the Libyan Central Bank in April 2005. As such, Libya ultimately paid $\$ 2.16$ billion of the originally agreed upon amount of $\$ 2.7$ billion. This was a difference of $\$ 2$ million less per family (\$8 million, instead of \$10 million). Christopher M. Blanchard \& Jim Zanotti, Libya: Background and U.S. Relations, CONG. RES. SERV., at 11, Feb. 18, 2011, http:// fpc.state.gov/documents/organization/157348.pdf; see also Libyan Central Bank Takes Back Last Batch of Compensation Money Due to Lockerbie Victims, AP WORLDSTREAM, ApR. 9, 2005.

112 Of the 78 killed, 66 were commercial passengers and 12 were crew-members.

113 See Michael Wines, 76 On Board Perish as Jet from Israel Explodes Off Russia, N.Y. TIMES, Oct. 5, 2001, at A1.

114 See Michael Wines, Ukraine Defense Chief Resigns Over Downing of Passenger Jet, N.Y. TIMES, Oct. 25, 2001, at A8; see also John Lumpkin, U.S. Intelligence Believes Ukrainian Surface to Air Missile Brought Down Airliner, AssociATED PRESS, Oct. 5, 2001.

115 See Ruzindana, supra note 2, at 1.

116 See Russia Agrees Airliner Payout, BBC News, June 14, 2014.

117 Seattle Times Staff, Prosecutors: 1 MH Passenger Had Oxygen Mask On, SEATtLE TimES (Oct. 9, 2014), http://seattletimes.com/html/nationworld/2024733780_apxnetherlandsukraineplane.html. 
did not immediately disintegrate upon impact with the missile. Later reports have questioned the accuracy of the theory that the plane immediately disintegrated at 33,000 feet, especially since at least one passenger may have had time to partially put on his oxygen mask, meaning that some passengers may have been remotely aware of the impact and that the plane was in serious distress before losing consciousness. Further, chunks of the plane did remain in pieces on the ground, which further detracts from the theory that the plane immediately disintegrated upon impact with the missile. Indeed, wreckage from the plane was scattered along a twenty-mile corridor in Western Ukraine.

Russia has denied any role in the attack on Flight 17. However, evidence surfaced immediately afterwards that the surface-to-air BUK missile system used in the attack went quickly back across the Russian border within twenty-four hours of the attack. ${ }^{118}$ Further, the missile system has not been offered up as evidence by the Russians. Similarly, the missile system supplied and utilized by the Russians is a type of system that cannot be easily utilized by untrained rebel outfits. ${ }^{119}$ The attack clearly came from the rebels' units, as verified by phone conversations intercepted by Ukraine, of the separatist rebels discussing shooting at and downing the aircraft. ${ }^{120}$ Despite pressure on Russia from the EU and US, Russia has disavowed all connection to the separatist units that fired on the plane or the BUK missile system (despite the fact that the mobile surface-to-air weapon's system was spirited from East Ukraine back across the border into Russia within twenty-four hours after the attack). ${ }^{121}$ Incredibly, Russia even suggested that the responsibility for downing the plane likely rested with the Ukrainian government. ${ }^{122}$ As of the date of this article, it is unclear whether Russian

118 See, e.g., Will Stewart and Mia De Graaf, Is This the BUK Missile Launcher that Shot Down MH 17 Down Being Smuggled Back to Russia: Motorist Captures Military Truck Carrying BUK M1 in Border Town, UK DAILY MAIL NEWS ON-LINE, July 20, 2014, http://www.dailymail.co.uk/news/article2699170/Is-BUK-missile-launcher-shot-MH17-smuggled-Russia-Motorist-captures-military-truckcarrying-BUK-M1-border-town.html.

119 Bart Jansen and Jane Onyanga-Omara, Dutch Investigators Say Buk Missile Downed Malaysia Airlines Flight 17, USA TODAY, Oct. 13, 2015, http://www.usatoday.com/story/news/world/ 2015/10/13/dutch-release-malaysia-airlines-flight-17-crash-report/73847856/.

120 See MH17 Crash: Ukraine Releases Alleged Intercepts, BBC News (July 18, 2014); http:// www.bbc.com/news/world-asia-28362872; see also Will Stewart, Extraordinary Bugged Calls Between Rebels Suggest MH17 Was Shot Down with Missile Smuggled into Ukraine by Russian Military, DAILYMAIL.COM (Mar. 30, 2015), http://www.dailymail.co.uk/news/article-3018261/Bugged-callsrebels-suggest-MH17-shot-missile-smuggled-Ukraine-Russian-military.html.

121 See Stewart, supra note 120, at 1.

122 See, e.g., Associated Press, US dismisses Russian MH17 pictures that blame Ukraine for disaster, THE GuARDIAN, Nov. 15, 2014, http://www.theguardian.com/world/2014/nov/15/ukrainefighter-shot-mh17-claims-russian-tv-photo-fake (last accessed on October 19, 2015); see also Krishnadev Calamur, Who Brought Down Flight MH17?, The AtLanTic, Oct. 13, 2015, http:// www.theatlantic.com/international/archive/2015/10/who-brought-down-flight-mh17/410245/. 
advisers were present with the Ukraine separatists who fired the missile, had a role in firing the missile themselves, or trained the rebels and supported the separatists with the missile and missile system.

According to one article, "attacks on commercial aircraft by irregular forces such as Ukraine's separatists are far more frequent, particular on cargo aircraft." 123 David Gero, an expert on aviation law and aviation accidents, estimated that there are "quite a few cases," and "probably about two dozen," examples of irregular forces downing planes. ${ }^{124}$ In those cases, "restitution almost never is paid," and "no actions are taken against the perpetrators." 125 However, these are instances were no connections were established to a sovereign nation-state. On the other hand, according to Malcolm Shaw, an expert on the international law ramifications of the use of military force on civilian aircraft, "if Russia agreed to go to, say, the International Court of Justice, and, say, you can prove that Russia had sufficient control over the rebels to be held responsible for its actions, then you could get compensation." 126 While there are multiple ICJ cases discussing the principle of indirect responsibility, one citation or reference should adequately illustrate the point here. In United States $v$. Nicaragua, the ICJ made clear in its decision that it was a violation of international law for a State "to intervene, directly or indirectly, with or without armed force, in support of an internal opposition in another State." 127 The ICJ also found that a nation "will also, if they directly or indirectly involve the use of force, constitute a breach of the principle of non-use of force in international relations." 128

\section{PART II: CURRENT INTERNATIONAL LAW REGARDING THE UsE OF MILITARY ForCE AgAINST CIVILIAN AIRLINERS}

Like other domestic legal systems, international law is comprised of many different sources of international law, including treaty law, customary international law, and general principles of law recognized by the world community. While academic scholars sometimes engage in esoteric arguments about exactly what constitutes international law, a definitive itemized definition of "International Law" is contained in Article 38(1) of the International Court of Justice Statute. ${ }^{129}$ This itemized definition of

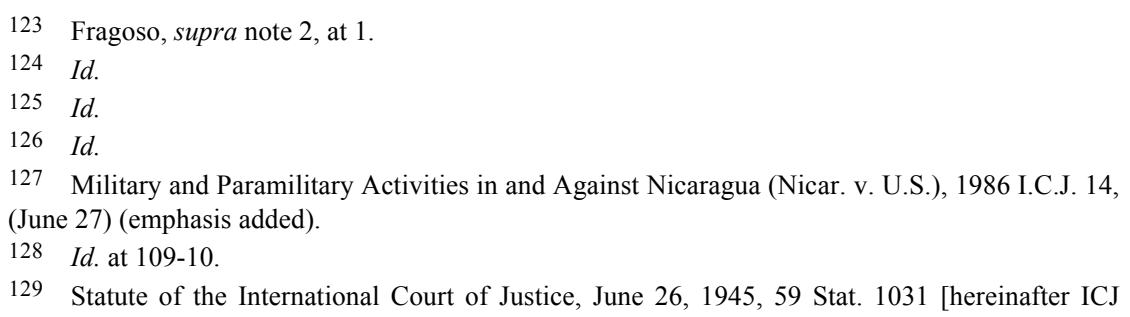


international law (in its many facets) is binding on every member of the United Nations by virtue of Article 93(1) of the U.N. Charter, which specifies that "all Members of the United Nations are ipso facto parties to the Statute of the International Court of Justice." Thus, the comprehensive and binding definition of International Law, as contained in Article 38(1) of the Statute of the International Court of Justice, is as follows:

The Court, whose function is to decide in accordance with international law such disputes as are submitted to it, shall apply:

International conventions, whether general or particular, establishing rules expressly recognized by the contesting States;

International custom, as evidence of a general practice accepted as law;

The general principles of law recognized by civilized nations;

Subject to the provisions of Article $59,{ }^{130}$ judicial decisions and the teachings of the most highly qualified publicists of the various nations, as subsidiary means for the determination of rules of law.

As renowned international law scholar Mark Janis has written, the ICJ statute provision defining international law puts treaties and conventions "first in its list of the rules to be applied by the Court in deciding cases before it, and most observers assign legal rules drawn from international agreements the highest rank among all the sources of international law."131

As such, an analysis of any obligations of nation states to refrain from the use of military force against civilian aircraft must start with an analysis of germane and relevant treaty law, the biggest of which in this field is the Chicago Convention on International Civil Aviation.

\section{A. Chicago Convention on International Civil Aviation and Article 3 bis}

The Chicago Convention (short for Convention on International Civil Aviation $)^{132}$ is considered one of the cornerstones and part of the foundation of modern international rules regarding aviation. It remains one of only a handful of especially germane and seminal foundational legal documents in this area. The Chicago Convention was signed as a proposed new treaty on December 7, 1944, and ultimately became legally effective with the

\footnotetext{
Statute].

$130 I d$. Article 59 rejects the common law concept of stare decisis and specifies that ICJ decisions have no precedential value and "no binding force except between the parties and in respect of that particular case."

131 MARK JANis, AN INTRODUCTION TO INTERNATIONAL LAW 10-11 (Aspen Law \& Business, 3d ed. 1999).

132 See Chicago Convention, supra note 8.
} 
ratification of the twenty-six member state on April 4, 1947. ${ }^{133}$ As of 2014, virtually the entire world is now a member of this seminal international treaty, 191 countries in total, including nearly every member of the United Nations (with the exception of Liechtenstein, Dominica, and Tuvalu). ${ }^{134}$ The Chicago Convention covers a bevy of provisions covering multiple aspects of air travel, including such diverse topics as the international rules of airspace, ${ }^{135}$ safety issues, ${ }^{136}$ rules for landing at customs airport, ${ }^{137}$ rules pertaining to the ability of a nation to search an aircraft from another country before landing or takeoff, ${ }^{138}$ and many others. ${ }^{139}$ Finally, the Chicago Convention created the International Civil Aviation Organization (ICAO), which became a specialized agency in its own right after 1945, charged with certain administrative, investigatory, and adjudicatory functions. In the ensuing years, the Chicago Convention has been significantly revised on eight subsequent occasions. ${ }^{140}$

Even at the onset, and before the first set of amendments in 1959, there were several key provisions that have bearing on this article. First, the Chicago Convention starts out with a reaffirmation of nation-state sovereignty in Article 1, stating that every state has "complete and

133 As a matter of international law and treaty law, treaties typically do not become legally binding upon signatures of representatives of the various countries present at the formation stage (unless expressly provided for in the treaty itself). Rather, treaties typically become legally effective and binding when a certain number of countries have approved of the treaty through the each country's domestic legal process, and deposits its "instruments of ratification" at the specified location. E.g., MARK JANIS, AN INTRODUCTION TO INTERNATIONAL LAW 20-21 (Aspen Law \& Business, 4th ed. 2003) (noting that "unlike the making of contracts in municipal law, the signing of a treaty cannot usually be assumed to constitute an acceptance by a party" and that ratification is the common way in which nations agree to their consent to be bound by treaty obligations). The specified depository location for the Chicago Convention is with the United States. Articles 91(b) and 92(b) of the Chicago Convention specified that the treaty would become legally binding 30 days after receiving the "instruments of ratification" from the requisite number of states. A complete list of countries that have since ratified the convention (and date of each country's ratification) can be found at the International Civil Aviation Organization's website at http://www.icao.int/publications/Documents/chicago.pdf.

134 See id.

135 See, e.g., Chicago Convention, supra note 8 at arts. 1, 2, 5, 12.

136 See, e.g., id. at arts. 14, 25 (Article 14 is entitled "Prevention of Spread of Disease" and Article 25 deals with topic and is entitled "Aircraft in Distress").

137 See id., at arts. 23, 24 (Article 23 is entitled "Customs and Immigration Procedures" and Article 24 is entitled "Customs Duty").

138 See id., at art. 16 (Article 16 is entitled "Search of Aircraft").

139 There are 96 different articles to the Chicago Convention covering an array of different topics (topics not relevant to the focus of this article) too numerous to delineate in this article, and well beyond the several brief examples of the breadth of the treaty coverage discussed in the text of this article.

140 The Chicago Convention was subsequently revised in 1959, 1963, 1969, 1975, 1980, 1997 , 2000 and 2006. See International Civil Aviation Organization, Convention on Civil Aviation-Doc 7300, ICAO.INT, http://www.icao.int/publications/Pages/doc7300.aspx, http://www.icao.int/publications/ Pages/doc7300.aspx (list of amendment dates at end of document). 
exclusive sovereignty over the airspace above its territory." ${ }^{, 141}$ Historically, this provision alone has been legal grounds for nations utilizing military force to down civilian aircraft, which violated the country's airspace. Second, Article 3(a) of the Chicago Convention excluded military aircraft from coverage of its provisions. ${ }^{142}$

However, almost immediately following the downing of KAL 007 in 1983 by the Soviet Union (discussed supra in Part I(e)), the legal terrain in this area began to shift. Shortly after this tragic event, the United Nations Security Council met in an emergency session and proposed a resolution that would have mandated that "such use of armed force against international civil aviation is incompatible with the norms governing international behavior." ${ }^{143}$ However, as one of the five permanent members of the U.N. Security Council with veto authority, the Soviet Union (quite expectedly) vetoed the proposed resolution. ${ }^{144}$ While not a maker of public international law itself, the ICAO still holds a great degree of adjudicatory and administrative authority, and is a respected specialized agency of the United States with a good amount of persuasive authority. Thus, the ICAO then convened an emergency meeting on September 15, 1983, roughly fourteen days after the incident, and passed a resolution condemning the actions of the Soviet Union and demanding that the Soviet Union take all necessary steps to aid in the recovery of the bodies of bereaving family members. ${ }^{145}$ Additionally, the resolution contained the following important verbiage, which in part informed subsequent changes to the Chicago Convention the following year (in Article 3 bis). ${ }^{146}$

At its most important point (for purposes of the future development of customary international law), the resolution contained the following provisions:

RECOGNIZING that such use of armed force against international

141 See Chicago Convention, supra note 8, at art. 1.

142 See id., at art. 3(a).

143 United Nations Security Council Consideration, 22 L.L.M. 1109, 1110 (1983); see also Foont, supra note 9 , at 702 .

144 See Phelps, supra note 9, at 262; see also Foont, supra note 9, at 708.

145 Id.

146 In addition to the ICAO's subsequent impact on the formation of important revisions to Article 3 of the Chicago Convention, the resolution is also relevant as a matter of customary international law (discussed infra in this article), as evidence of general practice of law of nations done out of a sense of legal obligation. That is, the resolution serves as evidence that an international lawyer can utilize in arguing that a country has a customary international law obligation to refrain from the utilization of military force against civilian aircraft (and help in recoveries, if such incidents occur), even if that country has not agreed to such as principle as a matter of treaty law. That is, the positive votes of countries for this resolution can be used as evidence and support for the argument that those countries have accepted the terms of the resolution as a matter of customary international law. See, e.g., JANIS, supra note 131, at 48-52. 
civil aviation is incompatible with the norms governing international behavior and elementary considerations of humanity and with the rules, Standards and Recommended Practices enshrined in the Chicago Convention and its Annexes and invokes generally recognized legal consequences,

REAFFIRMING the principle that States, when intercepting civil aircraft, should not use weapons against them. ${ }^{147}$

Indeed, the resolution contained many important statements. While the resolution clearly condemned the actions of the Soviet Union in using military force against a civilian aircrafts, it also put forth other important principles. For instance, the resolution condemned the Soviet Union's then ongoing obstruction in the investigation in the case-including its refusal to help identify the possible location of human remains in the water. It also condemned the Soviet Union for the Soviet's reluctance and refusal to aid in the recovery of important evidence. The Soviets where further condemned by failing to return recovered personal possessions to grieving family members. Finally, the resolution requested further United Nations actions in pressuring a non-compliant Soviet Union to assist in the investigation. ${ }^{148}$ However, for purposes of this article, the two most important provisions in terms of the subsequent amendment to the Chicago Convention in this area were in the above two reproduced provisions.

Thus, a year later, on May 10, 1984, with the downing of KAL 007 still very much raw in the minds and hearts of many, the ICAO Assembly unanimously adopted Article 3 bis to the existing Chicago Convention, ${ }^{149}$ with revisions in large part influenced by the language of its previous resolution (cited above). However, because the amendment to the Chicago Convention (in adding a new provision) required the ratification of the member states, ${ }^{150}$ the "new" Article 3 bis was not actually enacted until fourteen years later on October 1, 1998, when the requisite number of member state ratifications was finally garnered. ${ }^{151}$ Article 3 bis was clearly

147 International Civil Aviation Organization (ICAO) Consideration, 22 I.L.M. 1149, 1150 (1983); see also ICAO Bulletin, November 1983, at 10.

148 For a more complete delineation of the resolution, see Foont, supra note 9, at 709.

149 See International Civil Aviation Organization, Administrative Package for Ratification of the Protocol on Article 3 bis, ICAO.INT, http://www.icao.int/secretariat/legal/Administrative\%20Packages/ 3bis_en.pdf (last visited on Oct. 19, 2015).

150 Article 94 of the Chicago Convention mandates that "any proposed amendment to this Convention must be approved by a two-thirds vote of the Assembly and shall then come into force in respect of States which have ratified such amendment when ratified by the number of contracting States specified by the Assembly. The number so specified shall not be less than two-thirds of the total number of contracting States." Chicago Convention, supra note 8, at art. 94.

151 ICAO, Assembly Resolutions in Force (as of 5 October 2001), at I-6 to -I-9, ICAO Doc. 9790 (1st ed., 2002). 
prompted by the KAL 007 tragedy, and as such, sets forth three basic principles: first, "the obligation of States to refrain from resorting to the use of weapons against civil aircraft in flight;" second, "the obligation, in case of interception, not to endanger the lives of persons on board and the safety of aircraft;" and third, "the right of States to require a civil aircraft flying above its territory to land at a designated airport without authorization or, if there are reasonable grounds, to conclude that it is being used for any purpose inconsistent with the aims of the Convention." 152 Indeed, in the official "Administrative Package for Ratification of the Protocol on Article $3 B I S$," the official model ratification package recommended that the "[m]ain reasons for ratification" portion include the following language, in its entirety, "The use of weapons against civil aircraft in flight is incompatible with elementary considerations of humanity and the norms governing international behavior. Article 3 bis embodies fundamental principles essential for the safe development of international civil aviation." 153

For purposes of this article, it is important to quote Article 3 bis in its entirety (but excluding the preamble to the new Article 3 bis) ${ }^{154}$ It reads as follows:

The contracting States recognize that every State must refrain from resorting to the use of weapons against civil aircraft in flight and that, in the case of interception, the lives of persons on board and the safety of aircraft must not be endangered. This provision shall not be interpreted as modifying in any way the rights and obligations of States set forth in the Charter of the United Nations. ${ }^{155}$

The contracting States recognize that every State, in the exercise of its sovereignty, is entitled to require the landing at some designated airport of a civil aircraft flying above its territory without authority or if there are reasonable grounds to conclude that it is being used for any purpose inconsistent with the aims of this Convention; it may also give such aircraft any other instructions to put an end to such violations. For this purpose, the contracting States may resort to any appropriate means consistent with relevant rules of international law, including the relevant provisions of this Convention, specifically paragraph (a) of

152 ICAO, Agenda Item 5.6 Ratification of Article 3 bis of the Chicago Convention on International Civil Aviation, ICAO.int (Aug. 4, 2014), http://www.icao.int/NACC/Documents/Meetings/ 2014/NACCDCA5/NACCDCA5WP09.pdf, at 3.

153 Id. at Appendix B.

154 See International Civil Aviation Organization, Article 3 bis Protcol Relating to an Amendment to the Convention on International Civil Aviation, MCGILL.CA, http://www.mcgill.ca/iasl/files/iasl/ montreal1984.pdf (last visited Feb. 10, 2015).

155 Id. (emphasis added). 
this Article. Each contracting State agrees to publish its regulations in force regarding the interception of civil aircraft.

Every civil aircraft shall comply with an order given in conformity with paragraph (b) of this Article. To this end each contracting State shall establish all necessary provisions in its national laws or regulations to make such compliance mandatory for any civil aircraft registered in that State or operated by an operator who has his principal place of business or permanent residence in that State. Each contracting State shall make any violation of such applicable laws or regulations punishable by severe penalties and shall submit the case to its competent authorities in accordance with its laws or regulations.

Each contracting State shall take appropriate measures to prohibit the deliberate use of any civil aircraft registered in that State or operated by an operator who has his principal place of business or permanent resident in that State for any purpose inconsistent with the aims of this Convention. This provision shall not affect paragraph (a) or derogate from paragraphs (b) and (c) of this Article. ${ }^{156}$

After the Article 3 bis Protocol was open for ratification by member states, the ICAO also published a "Manual Concerning Interception of Civil Aircraft" in the attempt to provide some nuts-and-bolts examples on how to give practical meaning to Article 3 bis. ${ }^{157}$ In the attempt to avoid another similar incident like those in 1978 (Korean Airlines Flight 902) and 1983 (Korean Airlines Flight 007), the Soviet Union, Japan and the United States did execute a memorandum of understanding delineating procedures and establishing a communication protocol amongst these nations to avoid similar incidents in this historically problematic airspace corridor/route. ${ }^{158}$ It should also be noted that the tragic experience of KAL 007 was one of the factors in the United States making its GPS technology available for public usage.

In principle then, and as a general matter, Article 3 bis was meant to in essence mean that if an airplane did stray into the airspace of another, the country legally should not use military force, but rather require that the plane land. Of course, as well intentioned as Article 3 bis was (and especially considering the context in which Article 3 bis was even proposed and debated in the aftermath of the tragedy of KAL 007), numerous problems clearly still existed with operationalizing and fulfilling the true

156 Protocol Relating to an Amendment to the Convention on International Civil Aviation, 23 INT'L. LEGAL MATERIALS I.L.M 705, 706 (1984).

157 ICAO, Manual Concerning Interception of Civil Aircraft, Doc. 9433-AN/926 (2nd ed. 1990).

158 See Japan-United States-Union of Soviet Socialist Republics: Memorandum of Understanding Concerning Air Traffic Control, 25 INT’L. LEGAL MATERIALS I.L.M. 74 (1986). 
legislative intent and spirit of this article's amendment. First, as of 2014, just over $75.4 \%$ (144 parties) have ratified the amendment, of the 191 overall parties to the convention, meaning $24.6 \%$ of the overall parties to the Chicago Convention (191 parties to the convention overall) still have not ratified Article 3 bis, with the perhaps most notably non-ratifying country being the United States. ${ }^{159}$ While, according to the ICAO, the "United States committed to take actions during 2013 for the ratification of the protocol related to Article 3 bis of the Chicago Convention," 160 as of the end of 2014, the United States still has not ratified this important revision/ amendment. However, assuming universal adoption of article 3 bis at a future date, there are still changes needed to Article 3 bis to make it a meaningful addition to international law in this area, and not just a statement of an unenforceable platitude contained in the Convention. These limitations, and how to cure these deficiencies through subsequent international activity, will be addressed infra in Part III of this article.

However, setting aside the lack of complete universality of acceptance of Article 3 bis at present (or assuming arguendo that in the future all 191 member parties agreed to the amendment), there still are two additional major problems with Article 3 bis as drafted. First, there is no remedy provisions currently contained in the Chicago Convention for violation for Article 3 bis. That is, the Chicago Convention contains no provisions calling for compensation or reparations for a nation's violation of this prohibition against the use of military force against a civilian aircraft. Second, as one author has stated, Article " 3 bis is not a panacea in that the apparently unequivocal bar to the use of force against civil aircraft in flight in the first sentence is subject to an all-encompassing exception in the exception in the second." significantly limits the scope of the preceding first sentence by stating that "[t]his provision should not be interpreted as modifying in any way the rights and obligations of States set forth in the Chapter of the United Nations." ${ }^{162}$ Of course, in reviewing virtually all of the major incidents of a

159 A complete list of countries that have since ratified Article 3 bis of the convention (and date of each country's ratification) can be found at the International Civil Aviation Organization's website. Protocol Relating to an Amendment to the Convention on International Civil Aviation, ICAO.INT, http:// www.icao.int/secretariat/legal/List\%20of\%20Parties/3bis_EN.pdf (last visited Feb. 10, 2015).

160 Fifth North American, Central American and Caribbean Dirs. of Civil Aviation Meeting, Port-of-Spain, Trin. \& Tobago, Apr. 28-30, Ratification of Article 3 bis of the Chicago Convention on International Civil Aviation, ICAO, (Aug. 4, 2014), http://www.icao.int/NACC/Documents/Meetings/ 2014/NACCDCA5/NACCDCA5WP09.pdf, at 2.

161 Foont, supra note 9, at 711.

162 See International Civil Aviation Organization, Article 3 bis Protcol Relating to an Amendment to the Convention on International Civil Aviation, MCGILL.CA, http://www.mcgill.ca/iasl/files/iasl/ montreal1984.pdf (last visited Feb. 10, 2015). 
nation using force in downing an airline, the nation claims at some point in the aftermath of the tragedy its inherent right of self-defense as contained in Article 51 of the U.N. Charter, ${ }^{163}$ or in defense of its territorial integrity and/or unfettered rights of complete sovereignty and control of its territorial airspace. ${ }^{164}$ This may be why one law professor writing on the cusp of Article 3 being ratified by the requisite number of states, wrote, in part, that "it is expected that Article 3 bis will be adopted by the contracting states of the Chicago Convention. It is less certain whether the amendment will prevent another KAL-007 incident." 165

While nations certainly have the right to control and defend their airspace under Article 1 of the Chicago convention, ${ }^{166}$ virtually all of the incidents cited in Part I above involved nations utilizing military force because they believed (or at least claimed) some threat to their national security and self-defense - either to protect valuable military assets (e.g., to prevent spy planes from conducting surveillance over important strategic areas within a country, ${ }^{167}$ or that a country, like the United States in 1988, actually thought that the misidentified plane was involved in the threatened use of force against a U.S. warship during an on-going battle with Iranian gun boats occurring at the same time). ${ }^{168}$

\section{B. Prohibitions on the Use of Military Force Contained in the United \\ Nations Charter and the Exception of Self-Defense Contained in Article 51 of the Charter}

In analyzing the use of force of nations after World War II, the definitive rules are contained in the United Nations Charter, and most international legal scholars have stated that United Nations Charter put significant limitations on when a nation may legitimately utilize military force. ${ }^{169}$ Of course, the United Nations Charter is itself a treaty and a

163 See Phelps, supra note 9, at 301 (stating that "the only situation where force could be used against an aerial intruder would be in circumstances involving self-defense as defined by Article 51 of the United Nations Charter"); of course, since Phelps made this statement in 1985, there have been major multiple incidents involving the use of military force against civilian aircraft, in many cases not meeting the criteria of Article 51 of the U.N. Charter at all.

164 Article 1 of the Chicago Convention sets forth the basic principle at the very onset of ongoing nation-state sovereignty, and that "the contracting States recognize that every State has complete and exclusive sovereignty over the airspace above its territory." Chicago Convention, supra note 8, at art. 1 (emphasis added).

165 Phelps, supra note 9, at 303.

166 See Chicago Convention, supra note 8, at art 1.

167 See Fox, supra note 6 (reporting in part that KAL 007 was downed in 1983 by the Soviets because the "Soviet Union long maintained that the flight was a spy plane sent by the United States").

168 See Max Fisher, The Forgotten Story of Iran Airbus 655, WASH. PosT (Oct. 16, 2013), http:// www.washingtonpost.com/blogs/worldviews/wp/2013/10/16/the-forgotten-story-of-iran-air-flight-655/.

169 See JANIS, supra note 131, at 190-191. 
binding aspect of international law under Article 38(1)(a) of the Statute of the International Court of Justice. Indeed, in the guiding "purposes and principles" of the United Nations stated in Chapter One at the onset of the Charter, Article 2(4), for example, mandates that "all Members shall refrain in their international relations from the threat or use of force against the territorial integrity or political independence of any state, or in any other manner inconsistent with the Purposes of the United Nations." The striking down of another nation's civilian aircraft can certainly be classified as using force to the potential detriment of the political independence," or at least the sovereignty (and all that "sovereignty" entails), of another nation state. The use of military force must also not be in contravention of the "Purposes of the United Nations," which are clearly defined in the preamble to the Charter as including such things as the following:

To take effective collective measures for the prevention and removal of threats to the peace, and for the suppression of acts of aggression or other breaches of the peace, and to bring about by peaceful means, and in conformity with the principles of justice and international law, adjustment or settlement of international disputes or situations which might lead to a breach of the peace. ${ }^{170}$

Thus, nations are considered to be constrained in their usage of military force to very limited contexts, such as when the application of military force was specifically sanctioned by the United Nations Security Council or when a country engages in self-defense under Article 51 of the Charter.

Clearly, then, the largest and most germane exception to the prohibition on the "threat or use of force" by nations in the U.N. Charter is found in Article 51. Article 51 of the Charter of the United Nations provides as follows:

Nothing in the present Charter shall impair the inherent right of individual or collective self-defense if an armed attack occurs against a Member of the United Nations, until the Security Council has taken measures necessary to maintain international peace and security. Measures taken by in the exercise of this right of self-defense shall be immediately reported to the Security Council and shall not in any way affect the authority and responsibility of the Security Council under the present Charter to take at any time such action as it deems necessary in order to maintain or restore international peace and security.

Article 51 is clearly predicated on an "armed attack" occurring against 
a nation. Thus, shooting a plane down because it has veered several hundred miles off course (like the 1983 case of KAL 007) or that the plane was over a sensitive military base and perhaps spying (like the 1973 case of Libyan Airlines Passenger jet being shot down by Israel because it was over a military base) would not be permissible reasons to shoot down a plane under a self-defense claim under Article 51. Indeed, in the 1986 case Nicaragua v. United States (Military and Paramilitary Activities in and Against Nicaragua), the ICJ has held that "States do not have a right of ... armed response to acts which do not constitute an 'armed attack." "171 Finally, in perhaps one of the most famous articulations of the narrow right of self-defense in international law, Daniel Webster, as then-American Secretary of State, in response to an incident called the "The Caroline" incident, wrote in 1842 that "while it is admitted that exceptions growing out of the great law of self-defense to exist, those exceptions should be confined to cases in which the "necessity of that self-defense is instant, overwhelming, and leaving no choice of means, and no moment for deliberation." ${ }^{\prime 172}$ Thus, unless there was clear evidence of a civilian aircraft being utilized as a missile or means of conducting an "armed attack" (like what occurred in the United States on September 11, 2001), a nation should not be permitted to claim self-defense in using military force in striking down a plane simply for veering off-course or flying over restricted and sensitive military airspace. Clear evidence of the airline be utilized as a means of an armed attack would include facts like whether the plane had been hijacked, what were the demands of the hijackers (if any), background of the hijackers, et cetera.

\section{Customary International Law Obligations/Prohibitions under ICJ Statute} 38(1)(b) Regarding the Use of Military Force to Down Civilian Aircraft and any Customary International Law Obligations to Provide Reparations and Compensation for Any such Incidents

As defined by the Statute of the International Court of Justice, Article $38(1)$ (b), customary international law is defined as "international custom, as evidence of a general practice accepted by law." Phrased another way, in the words of international law scholar Mark Janis, "the fundamental idea behind the notion of custom as a source of international law is that states in and by their international practice may implicitly consent to the creation

171 Military and Paramilitary Activities in and Against Nicaragua (Nicaragua v. United States), 1986 I.C.J. 14, 103-23 (June 27, 1986).

172 LOUIS HENKIN, ET AL., INTERNATIONAL LAW: CASES AND MATERIALS, 872 (3d ed. 1993) (emphasis added). 
and application of international legal rules." ${ }^{173}$ Many scholars have suggested that customary law is much harder to prove than whether a concrete treaty provision exists, and whether a country has violated that treaty provision. ${ }^{174}$ Rather, "the determination of customary international law is more an art than a scientific method." ${ }^{175}$ It in essence requires an international lawyer to garner two major types of evidence: first, evidence of a relatively consistent a uniform practice of a state practice (or refraining from a practice) in a particular instance; and second that the practice was done out of "a sense of legal obligation." 176 Thus, it is not enough to show a consistent state practice in a particular area, but rather it must also be shown that a country engaged in that practice "must therefore feel that they are conforming to what amounts to a legal obligation. . . [and] the frequency, or even habitual character of the act is not in itself enough." 177 This requirement is more formally referred to as the requirement of opinio juris. ${ }^{178}$ The element of "opinio juris may be thought of as a solvent that transforms the nitty-gritty of a historical rendition of examples of state practice into a more liquid form: a rule of customary international law that may be applied to a current problem."179

For use of military force against civilian airliners, there are two "customary international law" issues: first, does customary international law prohibit of the use of military force through a general, consistent and uniform practice of done out of a sense of legal obligation (by the nationstate); and second, assuming that such a downing occurs, is there a customary international law obligation to provide compensation for such violations, as evidence of nations providing such compensation and doing so as a matter of a sense of "legal obligation"?

First, in terms of establishing that a state is engaged (or refrains from engaging) in a practice in a uniform and generally consistent fashion, the international lawyer must turn to the historical record to analyze state practice over time to see if a general, uniform and consistent practice (or refrain from a practice is occurring). This is one of the purposes for the historical rendition of the leading catastrophic air incidents which appeared supra in Part I of this article. Given the millions upon millions of flights ${ }^{180}$

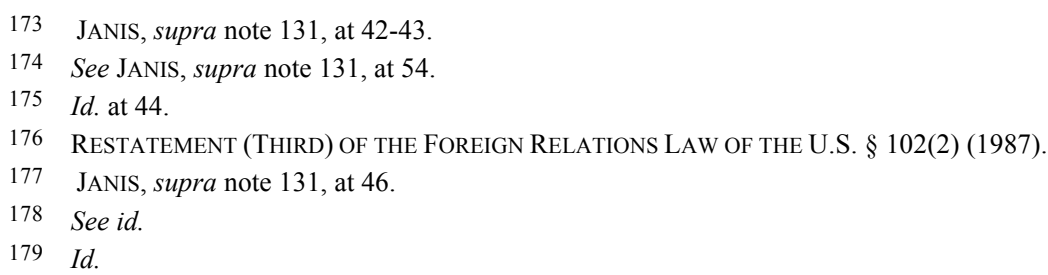

180 Just in 2014 alone, there were 100,000 flights scheduled per day, with 37.4 million flights scheduled for the entire calendar year 2014. In 2013, there were 99,726 flights per day, with 36,399,990 flights during the entire calendar year 2013. See Gunnar Garfors, 100,000 Flights a Day, Travel and 
that have certainly occurred since 1945 , and the fact that only a handful of flights have been disabled by military force, it would seem to suggest a general, consistent and uniform practice of nations trying to avoid this outcome and refrain from this practice - even when their air space has been infringed upon. In fact, between the years September 2001 and May 2005, in Canada and the United States alone, "military aircraft have intercepted more than 2,000 aircraft thought to be suspicious, but which all turned out not to be renegade aircraft." 181 Similarly, Germany scrambled military airplanes on at least twenty occasions in 2005 to chase suspicious planes, none of which turned out to be a hijacked plane or involved in an "armed attack" by using the plane as a missile. ${ }^{182}$ It light of these numbers, it could cogently and strongly be argued that there is a relatively general, uniform and consistent practice amongst nations against utilizing military force against airlines (unless they pose a threat as an "armed attack" under Article 51 of the U.N. Charter).

Again, however, in order to prove a customary international law obligation to refrain from shooting down airplanes, not only must a consistent state practice (or refrainment from action) be established, but that the country refrains from action out of a sense of legal obligation (i.e., opinio juris). Evidence of a country actually acting, or refraining from acting, out of a sense of legal obligation can be derived from numerous sources, including such things as the following: "formal state expressions of opinio juris," 183 executive agreements, legislation, Federal regulations, Federal court opinions, testimony and statements before Congressional and international bodies, diplomatic notes, correspondence, speeches, press conference statements, and even international memoranda." ${ }^{184}$ Of special usefulness in establishing the requisite opinio juris element of customary international law is the statements and writings of judges and jurists. ${ }^{185}$ The reason why the writings of jurists and judges are so important in this area is because Article 38(1)(d) of the Statute of the International Court of Justice sanctions and recommends "judicial decisions and the teachings of the most

Media (June 2, 2014), http://www.garfors.com/2014/06/100000-flights-day; see also PAUL S. DEMPSEY, AVIATION LIABILITY LAW vii (2d ed. 2013) (reporting similar numbers, with 31 million flights departing annually).

181 J.P. Edwards, The Law and Rules of Engagement Against Suicide Attacks, in NATO SCIENCE for Peace And Security Series, Human and Societal Dynamics, Suicide as a Weapon 135 (Centre of Excellence Defense against Terrorism ed., 2007).

182 Id.

183 JANIS, supra note 131 , at 47.

184 Id. at 48.

185 Id. at 47 ("Jurists and judges, rather than states, are often the more helpful sources for expressions of opinions that international practice has at some stage become customary international law."). 
highly qualified publicists of the various nations, as subsidiary means for the determination of rules of law." As Professor Janis has written, "jurists and judges, rather more frequently than states, are the effective brewers of that magic potion, opinio juris." 186

There have been a number of state articulations that the refrainment from the use of military force against aircraft should be practiced out of a sense of legal obligation. The spokesmen for many nations have made such statements, such as the Australian Minister of Foreign Affairs in 1983 stating that "there is no circumstance in which any nation can be justified in shooting down an unarmed civilian aircraft serving no military purpose" and the "fact that an aircraft may strayed into Soviet airspace ... provide no justification for an attack on an aircraft." 187 Likewise, Italy referred to the shoot-down "as a mad gesture of war." ${ }^{, 188}$ In 1959, again long before Article 3 bis, the Israeli government stated that "in normal times there can be no legal justification for haste and inadequate measures after interception of, and for the opening of fire on, a foreign civil aircraft, clearly marked as such." 189 Similarly, Great Britain "categorically rejected the use of force against a civil airliner under circumstances," absent very rigid and technical adherence to Article 51 of the U.N. Charter. ${ }^{190}$ Additionally, as discussed above, over 104 countries have agreed to this general principle by ratifying Article 3 bis of the Chicago Convention, ${ }^{191}$ except in cases involving a nation's right to engage in self-defense under the terms of Article 51 of the U.N. Chapter. ${ }^{192}$ Additionally, a number of delegates from different countries (including Australia, Austria, Canada, France, Italy, Japan, Netherlands, New Zealand, Pakistan, Korea, Switzerland, United Kingdom, and the United States) expressed the view that the prohibition on the use of military force against civilian aircraft was a firmly entrenched principle of customary international law. ${ }^{193}$ Second, such sentiments have also been expressed in the ICAO's resolution of 1983 which affirmed that

186 Id. at 48.

187 Korean Overseas InFORMation SERVICE, MASSACRE IN THE SKY: THE SOVIET DOWNING OF A KAL PASSENGER PLANE 39-40 (1983).

188 Shooting Down of South Korea Airliner by Soviet Fighter International Repercussions, KEESING'S RECORD OF WORLD EVENTS, Nov. 1, 1983, at 32513.

189 Concerning the Aerial Incident of 27 July 1955 (Israel v. Bulgaria), 1966 I.C.J. Pleadings, 168, 89 (May 26, 1959).

190 Phelps, supra note 9, at 283-284.

191 See supra note 154.

192 Phelps, supra note 9, at 297 (noting that the vote to forward Article 3 bis for ratification was unanimous by all the member states).

19338 ICAO Bulletin, June 1984, at 14-28. 
"such use of armed force against international civil aviation is incompatible with the norms governing international behavior and elementary considerations of humanity and with the rules, Standards and Recommended Practices enshrined in the Chicago Convention and its Annexes and invokes generally recognized legal consequences," and that "[s]tates, when intercepting civil aircraft, should not use weapons against them." 194

Furthermore, several nations have expressed clear rules of a "legal nature" in refraining from utilizing military force. Thus, for example, in Sweden, there are no acceptable circumstances in shooting down a civilian aircraft and such an act is flatly prohibited. ${ }^{195}$ Likewise, Germany's highest court, the Federal Constitutional Court, overturned a German anti-terrorist statute that would have authorized the government to shoot down a hijacked civilian aircraft, holding that such an action would be a violation of German constitutional law (and clearly an example of a need for Germany to refrain from such an activity in the future out of a sense of a legal obligation). ${ }^{196}$ Even in the United States, there are Rules of Engagement (ROE) after 9/11 meant to specify those instances when the law allows a shoot down (i.e., in response to the airplane being utilized as a missile in an "armed attack"), and when it does not. Thus, according to a former Commander of the North American Aerospace Defense (NORAD), "just because a plane has been hijacked is not a reason to shoot, it maybe [sic] an asylum or ransom seeker, or it may be just a false alarm." ${ }^{\text {197 }}$ Further, "under U.S. ROE, a civil aircraft flying would not be shot down if it was flying straight and level. However, if an aircraft had its nose down, and judged to be going to attack, then it would be shot down." 198 After 9/11, "U.S. ROE has been modified to state who has the authority to shoot down a threatening aircraft and in what circumstances." 199 Some countries, like Spain, have grappled with what actually constitutes an actual threat, and when, if at all, military force should be used to down a plane, especially in light of Article 3 bis of the Chicago Convention. ${ }^{200}$

Thus, while not conclusive, and certainly more evidence of opinio

194 ICAO Consideration, 22 I.L.M. 1149, 1150 (1983); ICAO Bulletin, November 1983, at 10.

195 Edwards, supra note 171, at 135; see also Craig Whitlock, German Court Overturns Law Allowing Hijacked Airliners to be Shot Down, WASH. PosT, Feb. 16, 2006, http:// www.washingtonpost.com/wp-dyn/content/article/2006/02/15/AR2006021501333.html.16.

196 Press Release, Bundes-Verfassungs-Gericht, Feb. 2006, 11/2006, https:// www.bundesverfassungsgericht.de/SharedDocs/Pressemitteilungen/EN/2006/bvg06-011.html.

197 Edwards, supra note 181, at 136.

198 Id.

199 Id.

200 Spain Powerless to Stop 11 September-style Attack on Madrid, EL PAIS, Mar. 11, 2002, http:// elpais.com/tag/fecha/20020311/. 
juris could be gathered than in the brief set of examples referenced above (which for purposes of brevity of this article I have foregone), there is a very strong argument to be made that there is also a customary international law prohibition on the use of military force against civilian aircraft, again unless the aircraft was being utilized in a fashion that constituted an "armed attack" against the country within the meaning of Article 51 of the U.N. Charter. That is, there seems to be a consistent, general and uniform practice to refrain from the actual application of military force against a civilian airliner (except in clear cases of the plane constituting an "armed attack") and a number of governments and courts have expressed that such a course of action should be followed out of a sense of legal obligation. Prominent law professors have argued the same. For example, John Phelps, in his seminal article entitled, "Aerial Intrusions by Civil and Military Aircraft in Time of Peace," had concluded by 1985 that "in the case of civil aerial intruders, the use of force is almost universally condemned except under the most extreme circumstances."201

However, there is another complex issue to address, whether there is a customary international law obligation to provide monetary damages in cases where a nation erred in its determination in whether the plane constituted a threat, and then erroneously applied military force in downing the civilian aircraft. In many cases where payment was subsequently made, the offending country was quick to point out that payments and compensation was not being provided out of a sense of legal obligation (or as an obligation of customary international law), but rather for compassionate and humanitarian reasons. The best example of this case may be seen in the aftermath of the U.S. downing of Iranian Flight 655 in 1988. In initially offering compensation to the families of the victims onboard this flight, President Reagan's Press Secretary (Marlin Fitzwater) stated that President Reagan wished to offer some compensation, but that "this offer of ex gratia compensation is consistent with international practice and is a humanitarian effort to ease the hardship of the families. It is offered on a voluntary basis, not on the basis of any legal liability or obligation. ${ }^{202}$ Further, in 1988, the United States made clear that payment made for international injuries may not necessarily mean that there was a "legal liability" mandating the United States to make such payments. As proof of this, the United States Department of State issued the following statement in 1988:

(1) indemnification is not required for injuries or damage incidental to

201 Phelps, supra note 9, at 292.

202 David Morgan, Past Commercial Airliners Shot Down by Military, Rebels, CBS News (July 18, 2014), http://www.cbsnews.com/news/past-commercial-airliners-shot-down-by-military-rebels/. 
the lawful use of armed force; (2) indemnification is required where the exercise of the armed force is unlawful; and (3) states may, nevertheless, pay compensation ex gratia without acknowledging, and irrespective of legal liability. ${ }^{203}$

Indeed, this position is consistent with several other notable cases referenced in Part I of this article, wherein countries would only provide compensation on an ex gratis fashion, while denying actual legal responsibility. Thus, Bulgaria offered only "ex gratis" payments to Israel for the 1955 shoot down of the Israeli El Al flight by Bulgaria. ${ }^{204}$ Similarly, Israel denied legal liability (or legal responsibility in offering compensation) in offering "ex gratis" payments to Libya in 1973, after Israel shot down a Libyan Airline Passenger jet. ${ }^{205}$ China's payment for the 1954 downing of the Cathay Pacific flight has also been deemed as an "ex gratis" payment. ${ }^{206}$ Finally, the Soviet Union denied any legal responsibility in the downing of KAL 007, and refused to make any meaningful efforts at compensation, despite the horrific potential deaths of the passengers on board that flight. ${ }^{207}$ Lawyers in the KAL 007 case argued that once Soviet missiles disabled the plane, the KAL 007 aircraft "entered into a controlled spiral descent that lasted for about 12 minutes. During that time, the passengers were alive," ${ }^{208}$ and subject potentially to unfathomable emotional turmoil, mental anguish, and pain and suffering, as the passengers plummeted to their most certain death during a twelve minute chaotic descent. Yet, the Soviets denied payment. Indeed, the Soviet's downing of a Korean Airlines Passenger Jet Flight 902 in 1978 (only five years prior to the KAL 007 incident), the Soviets also denied payment to the family members of two victims who perished when the plane was forced to make an emergency landing after being disabled. Thus, even in cases where a nation has made payments after downing an airplane, in many cases, the country takes pains to make clear that the payments were being made not out of a sense of legal obligation, but only an a humanitarian or "ex gratis" sense. As such, it is difficult to argue that mandatory compensation by a nation-state for these incidents is a new rule of customary international law that has emerged out of a general, consistent, and uniform practice, and one done out of a sense of legal obligation.

203 Abraham D. Soffear, Compensation of Iranian Airbus Tragedy, DEP'T OF STATE BuLLETIN, Oct. 1988, at 58 .

204 See supra notes 60-66.

205 See supra notes 73-74.

206 See supra notes 44-52.

207 See supra notes 89-92.

208 Court to Hear KAL 007 'Pain and Suffering' Claim, CNN INTERACTIVE (Apr. 27, 1998), http://www.cnn.com/US/9804/27/scotus.kal.shoot/. 


\section{A Jus Cogens Violation?}

What about a prohibition of shooting down planes as matter of a jus cogens violation? Jus cogens, known in the vernacular of the Vienna Convention on the Law of Treaties as a "peremptory norm," ${ }^{209}$ is considered such a fundamental principle of law so potent "that it even invalidates rules drawn from treaty or custom." ${ }^{210}$ It is therefore viewed as a type of "super" international law, which "cannot be derogated from by the will of the contracting parties." ${ }^{211}$ Phrased another way, jus cogens "is a sort of international law that, once ensconced, cannot be displaced by states, either in their treaties or in their practice" and "functions like a natural constitutional law that is so fundamental that states cannot avoid its force." ${ }^{212}$ At least one author has attempted to point out the possibility of this argument, primarily arguing that "the rule against targeting civilian objects in war, as codified in Article 52 of Protocol I to the Geneva Convention has passed into being a rule of jus cogens. ${ }^{213}$ Further, the author suggests "surely if there is a prohibition against targeting civilian targets in the conduct of war, a fortiori they may not be targeted outside the context of war." 214

However, as the author then accurately concludes, that it probably does not rise to the level of a jus cogens offense, as "it rests on the presumption that the rule is a peremptory norm, and there is no authoritative holding to that effect." 215 That is, jus cogens is a " norm accepted and recognized by the international community of states 'as a whole' as a norm from which no derogation is permitted." 216 That is, if nations have not uniformly and "as a whole" accepted the principle of refraining from using military force against airplanes, it is highly doubtful that an international arbiter such as the ICJ would view such action in violation of a preemptory norm of international law. In fact, "[p]artly because of its perceived potency, a peremptory norm is even more difficult to prove and establish than is a usually controversial rule of customary international law." ${ }^{217}$ The ICJ has

209 The Vienna Convention on the Law of Treaties, art. 53, May 23, 1996, U.N. Doc. A/CONF. 39/27, U.N.T.S. 336, reprinted in 63 AM. J. INT'L L. 875 (1969) (signed at Vienna on May 23, 1969; entered into force Jan. 27, 1989).

210 JANIS, supra note 131, at 62.

211 Alfred von Verdross, Forbidden Treaties in International Law, 31 AM. J. INT'L L. 571, 57172 (1937).

212 JANIS, supra note 131, at 64.

213 Foont, supra note 9, at 702.

214 Id. at 703.

215 Id.

216 The Vienna Convention on the Law of Treaties, art. 53, May 23, 1996, U.N. Doc. A/CONF. 39/27, U.N.T.S. 336, reprinted in 63 AM. J. INT’L L. 875 (1969) (entered into force Jan. 27, 1989).

217 JANIS, supra note 131, at 64. 
clearly delineated its disinclination to "enter into, still less pronounce upon question of jus cogens." ${ }^{218}$ Thus, it is very unlikely to do so in this instance. Indeed, over the years, there have been only a handful of principles of law so fundamental and universally accepted as such to have been held to be jus cogens. Few examples include such completely indefensible conduct under the international order such as slavery, piracy on the high seas, and genocide. Thus, jus cogens arguments do not yet appear to be viable grounds for action at the present time. As such, any meaningful enforcement (or needed changes to the existing rules) would best be effectuated through a further amendment/revision to Article 3 bis of the Chicago Convention. Therefore, possible revisions to Article 3 bis will be discussed next immediately below in this article.

\section{PART III: A CALL FOR REVISIONS AND CLARIFICATIONS TO EXISTING} RULES OF INTERNATIONAL LAW AND A CALL FOR "PUNITIVE DAMAGES" FOR NATION-STATES INVOLVED IN UTILIZING MILITARY FORCE IN DOWNing Planes Not Done In ACCORDANCE WITH ARTICLE 51 OF THE U.N. CHARTER

\section{A. Article 3 bis of the Chicago Convention Re-Visited}

As the reader will recall, Article 3(a) bis, mandates that "every State 'must refrain from resorting to the use of weapons against civil aircraft in flight' and that, in the case of interception, the lives of persons on board and the safety of aircraft must not be endangered." ${ }^{219}$ However, as laudable as the intentions and spirit of this provision were, this article has a number of problems. First, as pointed out previously in this article, there is no provision or statement mandating damages for nations who violate this basic provision. Second, the second sentence of Article 3(a) can be interpreted, and argued by a country, to have abrogated any obligation contained in the "mandate" contained in the first sentence. That is, immediately following the rule that "every State must refrain from resorting to the use of weapons" not be interpreted as modifying in any way the rights and obligations of States set forth in the Charter of the United Nations." 221 This second sentence can be said to negate the first sentence, and the rule to refrain from using military force, in two significant ways. First, as discussed previously,

218 North Sea Continental Shelf Cases (F.R.G. v. Den. \& Neth.), 1969 I.C.J. 3, 42 (Feb. 20, 1969).

219 Chicago Convention, supra note 154, Article 3 bis.

220 Id.

$221 \mathrm{Id}$. 
it leaves open the application of military force against airplanes when the nation believes it is correctly acting in self-defense under Article 51 of the U.N. Charter. Second, it is feasible that a nation may also argue that the general nature of sovereignty and exclusive control of one's territory (including its land, air, and territorial sea), which is affirmed in the U.N. Charter, negates any real obligation in the first sentence of Article 3 bis. More specifically, Article 2(7) of the U.N. Charter states as follows:

Nothing contained in the present Charter shall authorize the United Nations to intervene in matters which are essentially within the domestic jurisdiction of any state or shall require the Members to submit such matters to settlement under the present Charter; but this principle shall not prejudice the application of enforcement measures under Chapter Vll.

As such, Article 3 bis is defective in the broad open ended exception contained in the second sentence of Article 3(a). To make Article 3 bis more meaningful, the language should be revised in several significant ways. First, the second sentence of Article 3(a) should be revised to remove the vague language specifying that the prohibition against using military force against aircraft "shall not be interpreted as modifying in any way the rights and obligations of States set forth in the Charter of the United Nations." 222 Again, to make Article 3 bis more meaningful, the second sentence should specifically reference Article 51 of the U.N. Charter as the only legitimate possible exception to this prohibition against using force. Further, the revisions need to incorporate the express actual language of Article 51 in regards to a plane constituting an "armed attack," and specifically incorporate the language of the classic formulation of selfdefense found in the Caroline Case, wherein self-defense (i.e., military force against the aircraft) should only be utilized when the "necessity of that self-defense is instant, overwhelming, and leaving no choice of means and no moment for deliberation." ${ }^{223}$ Most, if not all, of the case examples cited in Part I of this article could have been avoided if the nation at issue had followed this restrictive, but classic and well-accepted articulation of when to employ force in "self-defense." A revision to this language would also put to rest the assumption that "every nation has the right and the obligation to protect itself and its people from hostile action, to include intelligence gathering activity." 224 As stated previously in Part I, several of the infamous cases involving nations utilizing military force against civilian aircraft were based (at least if public statements of the countries can be believed) on the

222 Id.

223 Henkin, supra note 172, at 872.

224 Phelps, supra note 9, at 292. 
need to protect the country from spying and intelligence related activities. While exclusive sovereignty of a country's airspace is guaranteed under Article 1 of the Chicago Convention (which arguably could include a country's claim that it has a right to preclude spying in its territorial airspace), protection from "intelligence gathering activity" is not within the meaning of an "armed attack" in the language of Article 51 of the U.N. Charter. Consequently, a country would be precluded in utilizing military force to shoot down planes engaged in intelligence activities alone. It is also important to note that under the current language of Article 3 bis, a nation retains the right to force the landing of a civilian plane in its territorial airspace, short of utilizing military force (again, unless an "armed attack" is transpiring against the country).

Finally, revising the language of the second sentence of Article 3(a) bis will also have the added benefit of negating possible claims by nations that they had a right to defend and prohibit airplanes in its airspace under Article 2(7) of the U.N. Charter. Article 2(7) of the U.N. Charter specifies that "nothing contained in the present Charter shall authorize the United Nations to intervene in matters which are essentially within the domestic jurisdiction of any state or shall require the Members to submit such matters to settlement under the present Charter; but this principle shall not prejudice the application of enforcement measures under Chapter VII." Further, as alluded to above, nations might attempt to fortify and bolster its arguments under Article 2(7) of the Charter by reference to Article 1 of the Chicago Convention as grounds for exercising absolute over its airspace, even to the degree of utilizing military force whenever the country deems proper. While predating Article 3 bis, this mentality was best phrased by Soviet Minister Andrei Gromyko in justifying the downing of KAL 007, when he said that "we state, in the Soviet territory the borders of the Soviet Union are sacred." ${ }^{, 25}$ Put simply, an aircraft's violation of Article 1 of the Chicago Convention, or a nation's right to control its territory under Article 2(7) of the U.N. Charter, should not be able to negate or deflect liability under the terms of Article 3 bis.

In light of a seemingly strong customary international law obligation not to use military force against civilian aircraft, why is there the need to revise Article 3 bis? First, there is a great "inelegance"226 of customary international law. It is difficult to prove and often involves gathering a great amount of evidence to support a state practice done out of sense of legal obligation. The advantage of a future amendment to Article 3 bis is the

225 Secretary of State George Shultz quoting Andrei Gromyko in a statement made in Madrid, Spain, on September 7, 1983. DeP'T OF StATE Bulletin, Oct. 1983, at 1, 3.

226 JANIS, supra note 131, at 53. 
same advantage as to why Article 3 bis was put forth in the first place-as an advantage over customary international law. As stated by the President of the twenty-fifth Session of the ICAO Assembly:

There may be some who believe that the prohibitions of use of force against civil aircraft is already a firm art of general international law and there is no need to codify that provision in the body of the Convention. However, the international community believes that only written law can remove the uncertainties of the other prime source, customary international law; it fills existing gaps in the law and gives precision to abstract general principles, the practical applications of which have not been previously settled, a written rule is far superior to general principles recognized as customary law because frequently the very existence of a customary law or its exact scope and content may remain subject to challenge. ${ }^{227}$

Thus, while an argument can be made that customary international law already makes illegal the utilization of military force against civilian aircraft and that a country is legally liable for damages caused by violations, there inevitably are difficulties, subjectivities, and vagaries assorted with such assertions under customary international law. As international law scholar Mark Janis has written,

[w]ithout denigrating the considerable utility of customary international law, it must be admitted that this form of international law is subject to a number of sometimes crippling faults. First and foremost is the fact that oftentimes state practice is so diverse that it may be difficult or even impossible to find enough consistency of practice to warrant drawing a customary international legal rule from it.

As such, a revision to Article 3 bis would be the ideal approach in making improvements to the law in this area.

\section{B. Call for Punitive Damages for Violations of Article 3 bis}

Part of the rationale for the call to revise Article 3 bis is to tighten and clarify the prohibition against the use of force as specified above. Another reason would be to add a clause allowing for monetary damages for violations of Article 3 bis. ${ }^{228}$ As stated previously, an additional problem with the current version of Article 3 bis is that there are no provisions calling for actual monetary liability anywhere in Chicago Convention for

22738 ICAO Bulletin, June 1984, at 13.

228 The ICAO or the ICJ could easily be empowered to adjudicate violations to Article 3 bis and award appropriate remedies. 
violations of Article 3 bis. The lack of any monetary liability on nations for violations limits the actual potential power of Article 3 bis to change the behavior of nation states.

As pointed out in various sections above, and with the notable exceptions of the former Soviet Union (now Russia), most countries do provide some type of ex gratis payment for their wrongful actions in using military force against civilian aircrafts. Sometimes payment happens relatively quickly (like in the cases of the 1954 Cathay Pacific Flightwherein payment was demanded and made within a year) ${ }^{229}$ and sometimes the compensation takes years (like in the cases of the 1988 shoot down of Iran Flight 655 by the United States, wherein compensation was not provided until eight years later, ${ }^{230}$ or in the case of Libya's downing of the 1988 Pan Am 103 flight, wherein compensation from Libya was not provided until fifteen years later) ${ }^{231}$ Also, relatively speaking, and in this author's opinion, the amounts provided usually are low. With the exception of Libya's precedent setting payment in $2003,{ }^{232}$ the compensation offered by nations has ranged anywhere from $£ 36,700$ per family member for each of the victims ${ }^{233}$ killed in the 1954 incident to $\$ 200,000$ per family member of each deceased victim on board Flight 1812 shot down by the Ukrainians in $2001{ }^{234}$ Even the United States' compensation of the family members for the downing of the Iranian Airbus, amounted only to approximately $\$ 213,103$ per family member. ${ }^{235}$ Yet, when one considers the grievousness of the conduct of nations in using military force against unarmed and vulnerable civilians, the expansive wealth and resources of these countries (i.e., the ability to pay higher amounts), and the horrible deaths that many passengers presumably suffered on board these disabled planes before they crashed, the victims' families are entitled to more. ${ }^{236}$ Thus, in the KAL 007

229 See supra notes 44-52.

230 See supra note 101.

231 See supra notes 104-109.

232 Id.

233 China paid $£ 367,000$ to settle all claims, excluding the amount that went to Cathay Pacific Airways Company for lost baggage and damage to the plane- - which compensation which came out of this same total settlement amount, this amounted to $£ 36,700$ to the families of each of the ten deceased occupants, and probably a lower amount-again given the other miscellaneous claims that needed to be paid as well. Under currency exchange rates in early 2015, this would amount to payment of approximately $\$ 54,893$ in U.S. currency.

234 See supra notes 113-114.

235 Of the $\$ 131$ million ultimately paid to Iran by the United States in 1996, only \$61.8 million went to the families of the victims of this destroyed aircraft. While the number of passengers onboard this Iranian airliner has varied among various sources, if one accepts the number of 290 souls on board the aircraft (the number of passengers certified to the ICJ in its pleadings against the United States), then the family members of each of these deceased individuals received approximately $\$ 213,103$ (i.e., $\$ 61.8$ million divided by 290 individuals).

236 These amounts appear even more nominal when one considers that the families of some 
incident, Juanita Madole, one of the plaintiffs' attorneys argued that the KAL 007 aircraft "entered into a controlled spiral descent that lasted for about 12 minutes. During that time, the passengers were alive."237 One could only imagine the pain and suffering and fear endured by these passengers during the last few minutes of their lives. ${ }^{238}$ In the most recent case of Malaysian Airline 17, for instance, the corpse of one of the passengers on Malaysia Airlines Flight 17 was found with an oxygen mask around neck/head, "raising questions about how much those on board knew about their fate when the plane plunged out of the sky above Eastern Ukraine in July." 239 Indeed, after a hearing of the evidence, the Dutch Foreign Minister, Frans Timmermans, quickly concluded that not everybody on board might have died instantly. ${ }^{240}$ In his later address to the U.N. Security Council, Minister Timmermans asked the Security Council members to imagine the possible pain and suffering and horror that could have been experienced by the passengers, and stated that "when they knew the plane was going down" did they look each other in the eyes "one final

victims of KAL 007 eventually were able to recover amounts upwards of $\$ 10$ million per claimant in some instances, and payable by the Korean Airlines and its insurers. Many of these payments were in out of court settlements, although one claimant was awarded \$2.1 million by a federal jury. See Fox, supra note 31. Certainly, therefore, more can and should be expected of nations, who typically possess vast holdings in land and material resources (let alone, in many cases, abundant state treasuries).

237 Court to Hear KAL 007 'Pain and Suffering' Claim, CNN INTERACTIVE (Apr. 27, 1998, 10:47 AM), http://www.cnn.com/US/9804/27/scotus.kal.shoot/.

238 In domestic litigation cases against airliners and their insurance companies, lawyers in this area refer to such damages as a "survival action," where the next of kin seek payment and damages for the deceased relatives' pain and suffering that may have been incurred in the seconds or minutes before a planes ultimate destruction. A number of hurdles obviously exist in litigation against the airline. In addition to proving misconduct on the part of the airline, it is incumbent on plaintiffs' lawyers show that the passengers were alive after, say a missile strike, and for how long. Obviously, the longer a passenger remained alive, conscious and therefore in a panicked state, the merit and strength of larger compensation payments becomes a reality in these domestic cases. Of course, this is an evidence issue that is many times very hard to prove when a plane disintegrates in air thousands of feet about land, or when the impact of the imperiled aircraft strikes the ground at such a speed that evidence is greatly mangled and damaged. Thus, it is also imperative that investigatory teams and forensic experts are able quickly access the accident/impact scene-which sometimes extends for miles. For instance, the debris field for the Malaysian Air Flight 17 wreckage was found over a very wide area of eastern Ukraine. In several high profile cases, like in the 1983 KAL 007 (wherein the Soviet Union clearly attempted to interfere and delay with the prompt investigation of the instance) and in the 2014 Malaysian Airlines Flight 17 (wherein Ukraine rebels did not properly secure evidence or the accident impact zone). The littlest details of forensic evidence also often times becomes of paramount importance. As such, in terms of proposed revisions to Article 3 bis, this article calls for a mandatory type of "punitive damages" regardless of these evidentiary issues of how long passengers actually survived.

239 Mike Corder, Prosecutors: 1 MH17 Passenger Had Oxygen Mask On, AP News (Oct. 9, 2014, 7:34 AM), http://www.aol.com/article/2014/10/09/prosecutors-1-mh17-passenger-had-oxygenmask-on/20975231/; see also MH 17 Crash: Dutch Minister Says Passenger 'Wore Oxygen Mask', BBC NEwS EUROPE (Oct. 9, 2014), http://www.bbc.com/news/world-europe-29548942.

240 MH 17 Crash: Dutch Minister Says Passenger 'Wore Oxygen Mask', BBC NEWS EUROPE (Oct. 9, 2014), http://www.bbc.com/news/world-europe-29548942. 
time, in an articulated goodbye. ${ }^{241}$ In such cases involving pain and suffering of such an unimaginable level, and a resource rich nation state actor, damages akin to punitive damages should be provided.

Thus, the concept of punitive damages in the American system may be a helpful analogy or model when considering the appropriate amount of damages payable to a victims' family by countries for their violations of international law in this area. Punitive damages in the American system can be asserted to compensate for certain types of egregious conduct to high amounts designed primarily as a form of punishment to the wrongdoer, and as a way to discourage future similar conduct. In the American system, as early as 1851 , the U.S. Supreme Court has held that these types of damages are proper as a way to "inflict what are called exemplary, punitive, or vindictive damages upon a defendant, having in view the enormity of his offense rather than the measure of compensation to the plaintiff." ${ }^{, 242}$ As explained by the U.S. Court of Appeals for the Second Circuit in a wellknown aviation disaster case, the U.S. Supreme Court has continued to adhere to that view through the present era. ${ }^{243}$ The Supreme Court "has characterized these damages as private fines used to punish a defendant's reprehensible conduct and to deter its repetition." ${ }^{244}$ As the United States Second Circuit Court of Appeals has pointed out, a majority of lower federal courts and a majority of state courts have held that the purpose of such high level of "punitive damages" is "penal" in nature, rather than "compensatory." 245 The Second Circuit also stated that "punitive damages are 'damages, other than compensatory or nominal damages, awarded against a person to punish him for his outrageous conduct and to deter him and others like him from similar conduct in the future." 246 This same system of damages should be employed by those nations who violate the standards of Article 3 bis of the Chicago Convention.

Despite some of the lower payments made by nations in the past, a strong precedent for more appropriate amounts of payment by nation-states

241 Id.

242 Day v. Woodworth, 54 U.S. 363, 370-71 (1851).

243 In re Air Disaster at Lockerbie, Scotland on December 21, 1988, 928 F.2d 1267, 1272 (2d Cir. 1991).

$244 I d$.

245 Id. The Second Circuit, in its opinion cites numerous cases as examples, such as Floyd v. Eastern Airlines, Inc., 872 F.2d 1462, 1486 (11th Cir. 1989) (stating that "[p]unitive damages are intended to penalize the wrongdoer in order to benefit society"); Harpalani v. Air-India, Inc., 634 F. Supp. 797, 799 (N.D. Ill. 1986) (stating that the purpose of damages is to punish and deter); Andor v. United Air Lines, Inc., 739 P.2d 18, 22 (Or. 1987) (stating that the "aim of punitive damages is punishment, deterrence of defendant and others from engaging in tortious conduct, and vindication of social norms").

246 In re Air Disaster at Lockerbie, 928 F.2d, at 1272. 
can be found by looking at the $\$ 2.7$ billion payment by Libya in $2003 .{ }^{247}$ As discussed previously, this amounts to roughly $\$ 10$ million per each life lost on board of the plane. Higher payments in this range clearly serve the purpose of the American notion of punitive damages discussed above, to punish the wrongdoer nation for outrageous conduct and attempt to deter such despicable conduct on future occasions by making the payments sufficiently significant that it might have the tendency to reform their conduct. As such, the concept of punitive damages, not by name, but by principle, should be codified into revisions of the Chicago Convention for purposes of violations of Article 3 bis.

Clearly, the ICJ is also empowered with rendering larger monetary awards against nations. There are indeed a number of $\operatorname{cases}^{248}$ that establish that the ICJ can impose monetary damages of sufficient amount to both compensate and "punish" the wrongdoer for violations of criminal law. For example, in the 2005 ICJ ruling in the case between the Democratic Republic of Congo and Uganda, the ICJ ordered Uganda to pay damages to the Congo for violating Article 2(4) of the U.N. Charter. ${ }^{249}$ The case stemmed from a claim that Uganda engaged in unlawful use of military force in Congo between the years 1998 and 2003. ${ }^{250}$ However, most relevant and germane to this article, the ICJ did two things of note in this case: first, the ICJ rejected Uganda's self-defense claims under Article 51 of the U.N. Charter; ${ }^{251}$ and second, the ICJ ruled that Uganda should actually pay significant reparations to Congo for these violations of law, which Congo estimated to be in the six to ten billion dollar range. ${ }^{252}$ Again, this reflects the ability of the ICJ to render these types of verdicts. Further, as one law professor has written,

[t]he mere declaration of that adds to the corpus of international law on the binding nature of treaties and may encourage treaty observations in

247 See supra notes 104-109.

248 See generally Mary Ellen O'Connell, The Prospects for Enforcing Judgments of the International Court of Justice: A Study of Nicaragua's Judgment Against the United States, 30 VA. J. INT'L L. 891 (1990) (demonstrating that in the Nicaragua case against the United States, Nicaragua asked the ICJ in its initial pleadings for an award of $\$ 12$ billion in reparations for claimed violations of international law).

249 Case Concerning Armed Activities on the Territory of the Congo (Democratic Republic Congo v. Uganda), Judgment, 2005 I.C.J. 168 (Dec. 19, 2005), available at http://www.icj-cij.org/ docket/files/116/10455.pdf. The judgment was based upon Uganda's threat and use of military force against the political integrity of the Congo.

250 Peggy McGuinnes, ICJ Orders Uganda to Pay Damages to the Democratic Republic of Congo for Illegal Incursion, OPINIO JURIS (Dec. 20, 2005, 8:27 AM), http://opiniojuris.org/2005/12/20/ icj-orders-uganda-to-pay-damages-to-the-democratic-republic-of-congo-for-illegal-incursion/.

251 This has obvious possible comparison with discussions contained supra in this article as part of an analysis of the meaning of Article 3 bis - and limiting the Article 51 exceptions thereto.

252 McGuinnes, supra note 250, at 1. 
the future. But a ruling that [a country] owes monetary damages followed shortly thereafter by enforcement of the award against the recalcitrant judgment debtor, would plainly make a greater impact. ${ }^{253}$

While nations have been generally reluctant to seek monetary damages against other states vis-à-vis the ICJ, that fact does not mean that the Court cannot render monetary judgments or that these judgments cannot be enforced as a matter of international law. ${ }^{254}$

Further, these cases should not be difficult to negotiate, resolve, or litigate, as a dispute mechanism process is built into the Chicago Convention. Specifically, Article 84 of the Chicago Convention provides as follows:

If any disagreement between two or more contracting States relating to the interpretation or application of this Convention and its Annexes cannot be settled by negotiation, it shall, on the application of any State concerned in the disagreement, be decided by the Council ... [Further] any contracting State may, subject to Article 85, appeal from the decision of the Council to an ad hoc tribunal agreed upon with the other parties to the dispute or to the Permanent Court of Justice. ${ }^{255}$

The 1988 Iranian litigation against the United States for the United States shooting down the Iranian Airbus is a perfect illustration of this international process. Iran first submitted a complaint to the ICAO Council per Article 84 of the Chicago Convention. ${ }^{256}$ In its "Application Instituting Proceedings" filed on May 17, 1989, Iran called for the following:

Condemnation of the shooting down of IR 655 by the United States

253 O'Connell, supra note 248, at 904-05.

254 The subject of enforcement of ICJ decisions is beyond the scope of this article. However, there are many articles and books which adequately address options nations have in "executing" on awarded ICJ judgments. See generally Mary Ellen O'Connell, The Prospects for Enforcing Monetary Judgments of the International Court of Justice: A Study of Nicaragua's Judgment against the United States, 30 VA. J. InT'L L. 891 (1990); Mohamed SAmEH M. AmR, THE Role OF THE INTERNATIONAL COURT OF Justice as the PRincipal Judicial ORgan of THE UNITED NATIONS (LEGAL ASPECTS OF INTERNATIONAL ORGANIZATION) (Kluwer Law International 2003); JANIS, supra note 131, at 125-55. Often times, the United Nations Security Council is in the best position to enforce international law, including judgments of the ICJ. Thus, for example, the United Nations Compensation Commission was established by United Nations Security Council Resolution 687 in 1991 to implement and enforce the Security Council determination that Iraq was in violation of international law in invading Kuwait. This body (the United Nations Compensation Commission) proceeded to effectuate a $\$ 50$ billion dollar judgment against Iraq.

255 The International Court of Justice is the descendant of the Permanent Court of Justice referenced in Article 84, and would therefore be the proper "court of last resort" within the meaning of Article 84 of the Chicago Convention.

256 Application Instituting Proceedings Submitted by the Government of the Islamic Republic of Iran, (Iran v. U.S.), 1989 I.C.J. General List No. 79, at 6 (May 17), available at https://www.icj-cij.org/ docket $/$ index.php?p1 $=3 \& \mathrm{p} 2=3 \&$ code $=$ irus $\&$ case $=79 \& \mathrm{~K}=9 \mathrm{c} \& \mathrm{p} 3=0$. 
military forces in the Persian Gulf.

Explicit recognition of a crime of international character relating to the break of international law and legal duties of [the United States as] a Contracting State of ICAO.

Explicit recognition of the responsibilities of the United States Government, and calling for the effecting compensation for moral and financial damages.

Demand for the immediate termination of present obstacles, restrictions, threats, and the use of force against civilian aircraft in the region, including the Council's appeal to relevant international bodies to demand the withdrawal of all foreign forces from the Persian Gulf. $^{257}$

While several of the demands were clearly political in nature and outside the authority of the ICAO (e.g., calling for the withdrawal of all foreign forces from the Persian Gulf), the petition did legitimately call for prompt financial remuneration (item number 3 above in the list of Iranian demands to the ICAO) ${ }^{258}$ However, the ICAO rejected the Iranian claims in a decision dated March 17, 1989, ${ }^{259}$ and, according to Iran, only briefly addressed its concerns, by stating the following: "[The ICAO] 'deeply deplores' the tragic incident which occurred as a consequence of events and errors in identification of the aircraft which resulted in the accidental destruction of an Iran Air airliner and the loss of 290 lives., ${ }^{260}$ After this rejection of its claims by the ICAO, Iran claimed that all attempts at subsequent mediation were "unsuccessful." 261 This ultimately prompted Iran to file suit in the ICJ against the U.S. on May 17, 1989. ${ }^{262}$ Additionally, if the ICJ were to have rendered a judgment in this case, ${ }^{263}$ the ICJ would be the "court of last resort," as Article 86 of the Chicago Convention goes on

257 Id.

$258 I d$.

259 The rejection of the ICAO as to the Iranian Claim can be found in Decision Taken by ICAO Council on IR 655 Tragedy, ICAO News Release No. PIO 4/89, March 17, 1989, and reproduced as an attachment to the Iranian Petition to the ICJ on May 19, 1989. Application Instituting Proceedings Submitted by the Government of the Islamic Republic of Iran, (Iran v. U.S.), 1989 I.C.J. General List No. 79, at 12-13 (May 17), available at www.icj-cij.org/docket/index.php?p1=3\&p2=3\&code= irus $\&$ case $=79 \& \mathrm{~K}=9 \mathrm{c} \& \mathrm{p} 3=0$ (containing a verbatim reproduction of the ICAO denial).

260 Application Instituting Proceedings Submitted by the Government of the Islamic Republic of Iran, (Iran v. U.S.), 1989 I.C.J. General List No. 79, at 6 (May 17), available at http:www.icj-cij.org/ docket $/$ index.php?p $1=3 \& \mathrm{p} 2=3 \&$ code $=$ irus $\&$ case $=79 \& \mathrm{~K}=9 \mathrm{c} \& \mathrm{p} 3=0$.

261 Id. at 8.

262 Application Instituting Proceedings Regarding Aerial Incident of 3 July 1988 (Iran v. U.S.), 1989 I.C.J. General List No. 79 (May 17), available at http://www.icj-cij.org/docket/index.php?p1= $3 \& \mathrm{p} 2=3 \&$ code $=$ irus $\&$ case $=79 \& \mathrm{~K}=9 \mathrm{c} \& \mathrm{p} 3=0$.

263 The ICJ did not have occasion to decide the case as the United States settled the case in 1996. 
to specify that "the decisions of the Permanent Court of Justice and of an arbitral tribunal shall be final and binding."

\section{PART IV: CONCLUSIONS}

While the evolution of law in this area has been laudable, especially since the unfortunate downing of KAL 007 in 1983, further revisions to Article 3 bis of the Chicago Convention are needed. Revisions are needed in the following ways: first, to narrow self-defense claims allowable under Article 3 bis (and only in those instances involving clear evidence of an actual "armed attack"); second, provide a provision indicating the compensation for violations of Article 3 bis will be paid by nations deemed to have violated Article 3 bis by either the ICAO or ICJ; and third, specify that those damages should be of a level that not only compensates the families of the victims in a fair fashion, but also is an amount that would sufficiently deter a country from engaging in such conduct again in the future.

Additionally, since all members of the Chicago Convention have agreed to ICJ jurisdiction, via the dispute resolution provisions contained in the convention, no additional changes to the convention are needed in that respect. Further, the ICJ is fully able to render judgments in a fashion advocated above and in a manner consistent with the level of compensation provided to the members of each family member who died on board Pan Am Flight 103 over Lockerbie, Scotland. The world community should expect nothing less from countries, ICJ, and public international law in general. 